\title{
LEVEL II SCOUR ANALYSIS FOR BRIDGE 23 (WOLCTH00130023) on TOWN HIGHWAY 13, crossing the WILD BRANCH LAMOILLE RIVER, WOLCOTT, VERMONT
}

U.S. Geological Survey

Open-File Report 97-394

Prepared in cooperation with

VERMONT AGENCY OF TRANSPORTATION

and

FEDERAL HIGHWAY ADMINISTRATION 


\section{LEVEL II SCOUR ANALYSIS FOR BRIDGE 23 (WOLCTH00130023) on TOWN HIGHWAY 13, crossing the WILD BRANCH LAMOILLE RIVER WOLCOTT, VERMONT \\ By EMILY C. WILD AND JAMES R. DEGNAN}

U.S. Geological Survey Open-File Report 97-394

Prepared in cooperation with

VERMONT AGENCY OF TRANSPORTATION and

FEDERAL HIGHWAY ADMINISTRATION 


\title{
U.S. DEPARTMENT OF THE INTERIOR BRUCE BABBITT, Secretary
}

\author{
U.S. GEOLOGICAL SURVEY \\ Gordon P. Eaton, Director
}

For additional information write to:

District Chief

U.S. Geological Survey 361 Commerce Way

Pembroke, NH 03275-3718
Copies of this report may be purchased from:

U.S. Geological Survey

Branch of Information Services

Open-File Reports Unit

Box 25286

Denver, CO 80225-0286 


\section{CONTENTS}

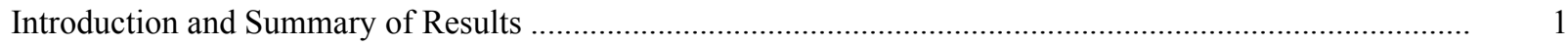

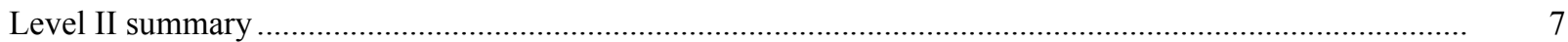

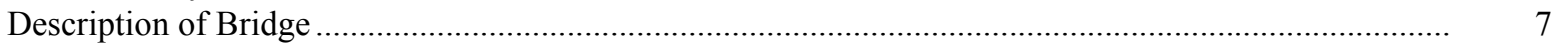

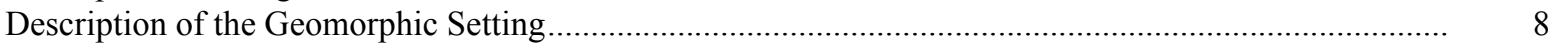

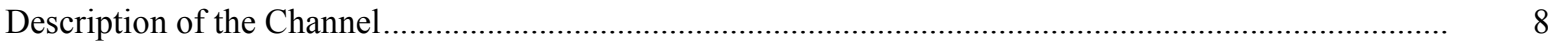

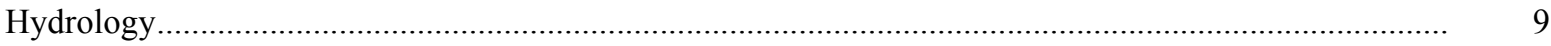

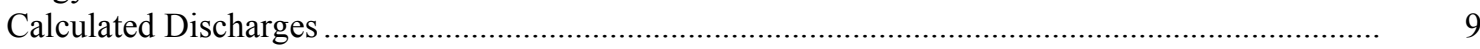

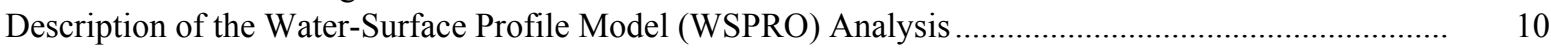

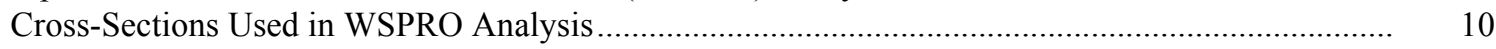

Data and Assumptions Used in WSPRO Model ...................................................................... 11

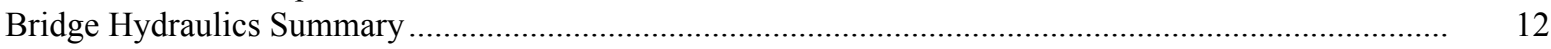

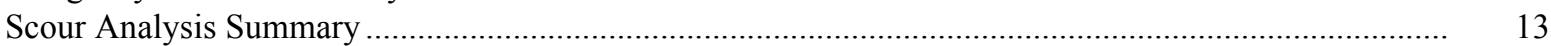

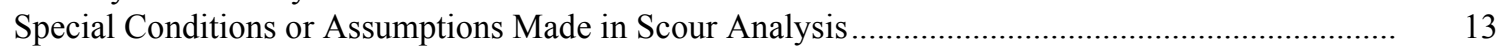

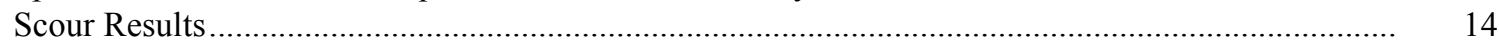

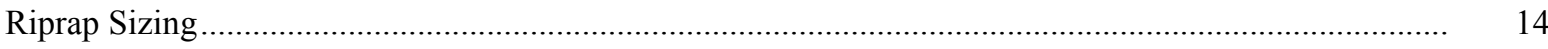

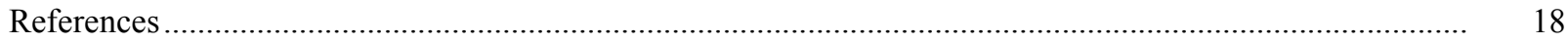

Appendixes:

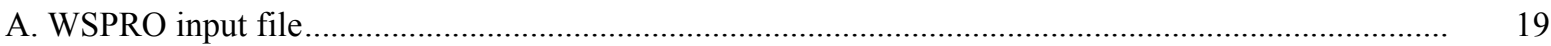

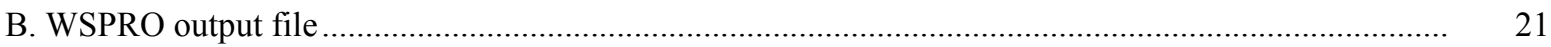

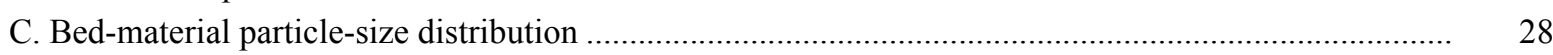

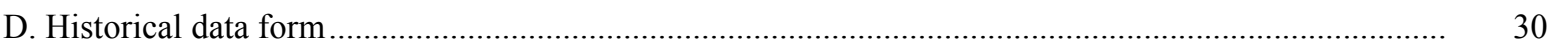

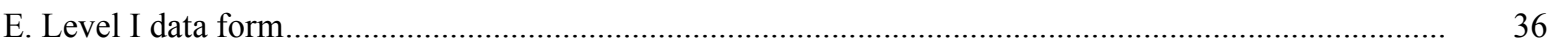

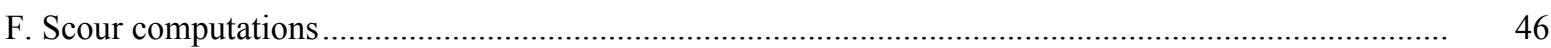

\section{FIGURES}

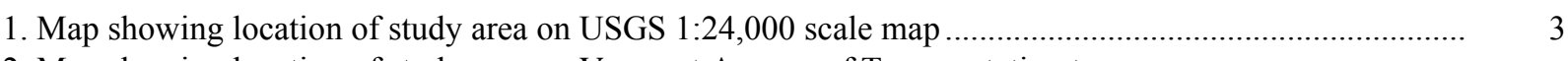

2. Map showing location of study area on Vermont Agency of Transportation town
highway map

3. Structure WOLCTH00130023 viewed from upstream (July 17, 1996) ..................................................

4. Downstream channel viewed from structure WOLCTH00130023 (July 17, 1996)............................. 5

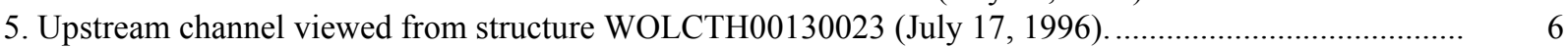

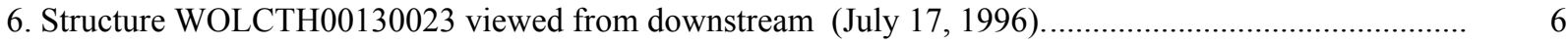

7. Water-surface profiles for the 100- and 500-year discharges at structure
WOLCTH00130023 on Town Highway 13, crossing the Wild Branch Lamoille River,

Wolcott, Vermont.

8. Scour elevations for the 100- and 500-year discharges at structure

WOLCTH00130023 on Town Highway 13, crossing the Wild Branch Lamoille River,

Wolcott, Vermont.

\section{TABLES}

1. Remaining footing/pile depth at abutments for the 100-year discharge at structure

WOLCTH00130023 on Town Highway 13, crossing the Wild Branch Lamoille River,

Wolcott, Vermont.

2. Remaining footing/pile depth at abutments for the 500-year discharge at structure

WOLCTH00130023 on Town Highway 13, crossing the Wild Branch Lamoille River,

Wolcott, Vermont..

5
(5) 


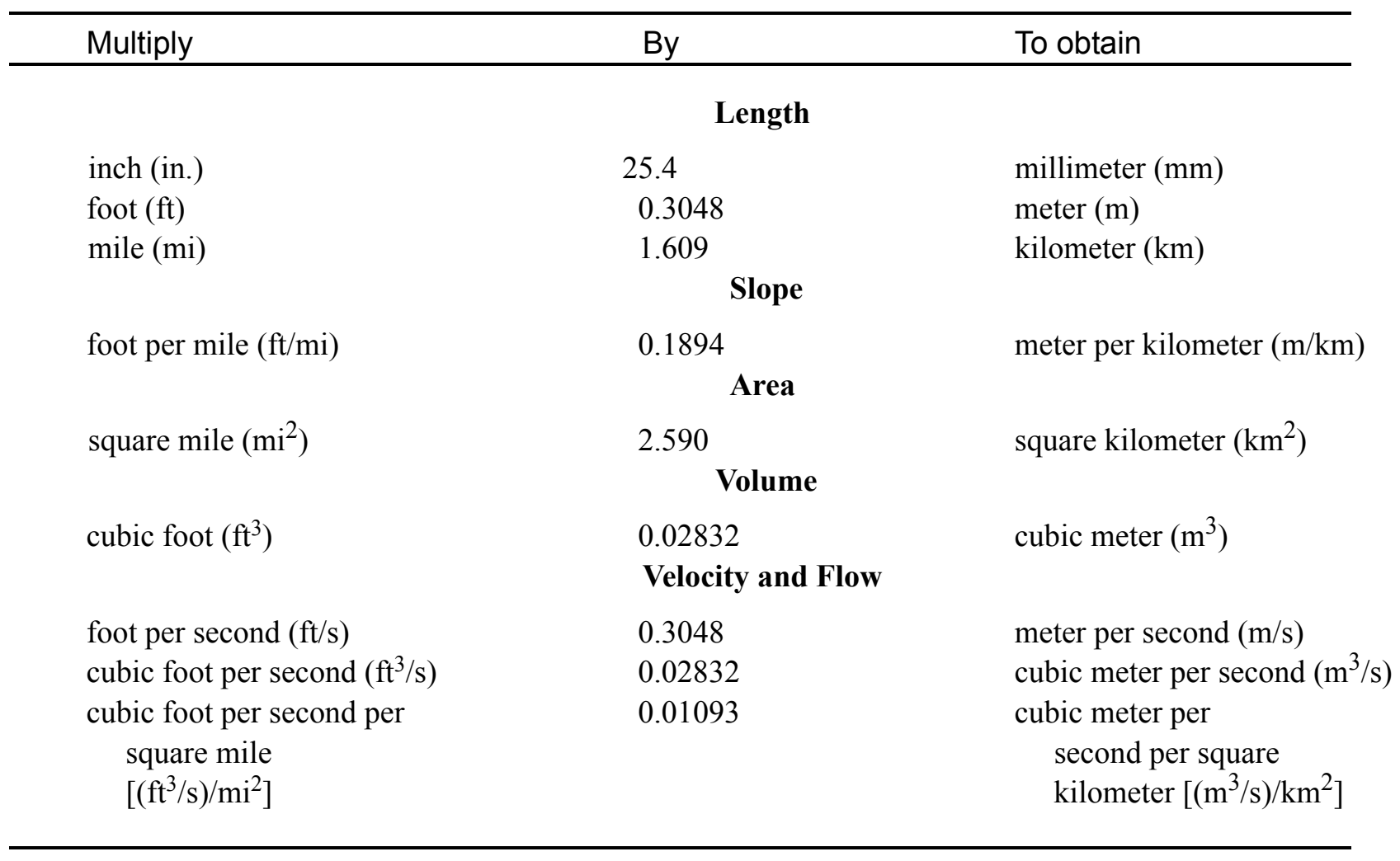

\section{OTHER ABBREVIATIONS}

$\begin{array}{lrlr}\mathrm{BF} & \text { bank full } & \text { LWW } & \text { left wingwall } \\ \mathrm{cfs} & \text { cubic feet per second } & \text { MC } & \text { main channel } \\ \mathrm{D}_{50} & \text { median diameter of bed material } & \text { RAB } & \text { right abutment } \\ \mathrm{DS} & \text { downstream } & \text { RABUT } & \text { face of right abutment } \\ \mathrm{elev} & \text { elevation } & \text { RB } & \text { right bank } \\ \mathrm{f} / \mathrm{p} & \text { flood plain } & \text { ROB } & \text { right overbank } \\ \mathrm{ft}^{2} & \text { square feet } & \text { RWW } & \text { right wingwall } \\ \mathrm{ft} / \mathrm{ft} & \text { feet per foot } & \text { TH } & \text { town highway } \\ \mathrm{JCT} & \text { junction } & \text { UB } & \text { under bridge } \\ \mathrm{LAB} & \text { left abutment } & \text { US } & \text { upstream } \\ \mathrm{LABUT} & \text { face of left abutment } & \text { USGS } & \text { United States Geological Survey } \\ \mathrm{LB} & \text { left bank } & \text { VTAOT Vermont Agency of Transportation } \\ \mathrm{LOB} & \text { left overbank } & \text { WSPRO } & \text { water-surface profile model }\end{array}$

In this report, the words "right" and "left" refer to directions that would be reported by an observer facing downstream. Sea level: In this report, "sea level" refers to the National Geodetic Vertical Datum of 1929-- a geodetic datum derived from a general adjustment of the first-order level nets of the United States and Canada, formerly called Sea Level Datum of 1929.

In the appendices, the above abbreviations may be combined. For example, USLB would represent upstream left bank. 


\title{
LEVEL II SCOUR ANALYSIS FOR BRIDGE 23 (WOLCTH00130023) ON TOWN HIGHWAY 13, CROSSING THE WILD BRANCH LAMOILLE RIVER, WOLCOTT, VERMONT
}

\author{
By Emily C. Wild and James R. Degnan
}

\section{INTRODUCTION AND SUMMARY OF RESULTS}

This report provides the results of a detailed Level II analysis of scour potential at structure WOLCTH00130023 on Town Highway 13 crossing the Wild Branch Lamoille River, Wolcott, Vermont (figures 1-8). A Level II study is a basic engineering analysis of the site, including a quantitative analysis of stream stability and scour (U.S. Department of Transportation, 1993). Results of a Level I scour investigation also are included in Appendix E of this report. A Level I investigation provides a qualitative geomorphic characterization of the study site. Information on the bridge, collected from Vermont Agency of Transportation (VTAOT) files, was compiled prior to conducting Level I and Level II analyses and is found in Appendix D.

The site is in the Green Mountain section of the New England physiographic province in northcentral Vermont. The $27.7-\mathrm{mi}^{2}$ drainage area is in a predominantly rural and forested basin. In the vicinity of the study site, the surface cover is pasture on the upstream right overbank. The upstream left overbank is brushland. Downstream of the bridge, the surface cover is forested on the right overbank. The downstream left overbank is pasture while the immediate bank has dense woody vegetation.

In the study area, the Wild Branch Lamoille River has an incised, straight channel with a slope of approximately $0.009 \mathrm{ft} / \mathrm{ft}$, an average channel top width of $65 \mathrm{ft}$ and an average bank height of $7 \mathrm{ft}$. The channel bed material ranges from sand to boulders with a median grain size $\left(D_{50}\right)$ of $85.3 \mathrm{~mm}$ $(0.280 \mathrm{ft})$. The geomorphic assessment at the time of the Level I and Level II site visit on July 17, 1996 indicated that the reach was laterally unstable.

The Town Highway 13 crossing of the Wild Branch Lamoille River is a 41-ft-long, one-lane bridge consisting of a 39-foot steel girder span (Vermont Agency of Transportation, written communication, October 13, 1995). The opening length of the structure parallel to the bridge face is $38 \mathrm{ft}$. The bridge is supported by vertical, concrete abutments. The right abutment has concrete wingwalls. The channel is skewed approximately 45 degrees to the opening while the openingskew-to-roadway is zero degrees. 
A scour hole $3.5 \mathrm{ft}$ deeper than the mean thalweg depth was observed in the channel during the Level I assessment. Scour countermeasures at the site includes type- 2 stone fill (less than 3 feet diameter) along the banks, the right wingwalls, the right abutment and the road embankments. Additional details describing conditions at the site are included in the Level II Summary and Appendices D and E.

Scour depths and recommended rock rip-rap sizes were computed using the general guidelines described in Hydraulic Engineering Circular 18 (Richardson and others, 1995). Total scour at a highway crossing is comprised of three components: 1) long-term streambed degradation; 2) contraction scour (due to accelerated flow caused by a reduction in flow area at a bridge) and; 3 ) local scour (caused by accelerated flow around piers and abutments). Total scour is the sum of the three components. Equations are available to compute depths for contraction and local scour and a summary of the results of these computations follows.

Contraction scour for all modelled flows ranged from 1.0 to $2.1 \mathrm{ft}$. The worst-case contraction scour occurred at the 100-year discharge. Left abutment scour ranged from 9.1 to $13.2 \mathrm{ft}$. Right abutment scour ranged from 15.7 to $22.3 \mathrm{ft}$. The worst-case abutment scour occurred at the 500year discharge for both abutments. Additional information on scour depths and depths to armoring are included in the section titled "Scour Results". Scoured-streambed elevations, based on the calculated scour depths, are presented in tables 1 and 2. A cross-section of the scour computed at the bridge is presented in figure 8. Scour depths were calculated assuming an infinite depth of erosive material and a homogeneous particle-size distribution.

During the August 1995 flood, the Wild Branch Lamoille River overtopped the bridge deck at structure WOLCTH00130023. Debris also was caught in the upstream I-beam of the structure.

It is generally accepted that the Froehlich equation (abutment scour) gives "excessively conservative estimates of scour depths" (Richardson and others, 1995, p. 47). Usually, computed scour depths are evaluated in combination with other information including (but not limited to) historical performance during flood events, the geomorphic stability assessment, existing scour protection measures, and the results of the hydraulic analyses. Therefore, scour depths adopted by VTAOT may differ from the computed values documented herein. 


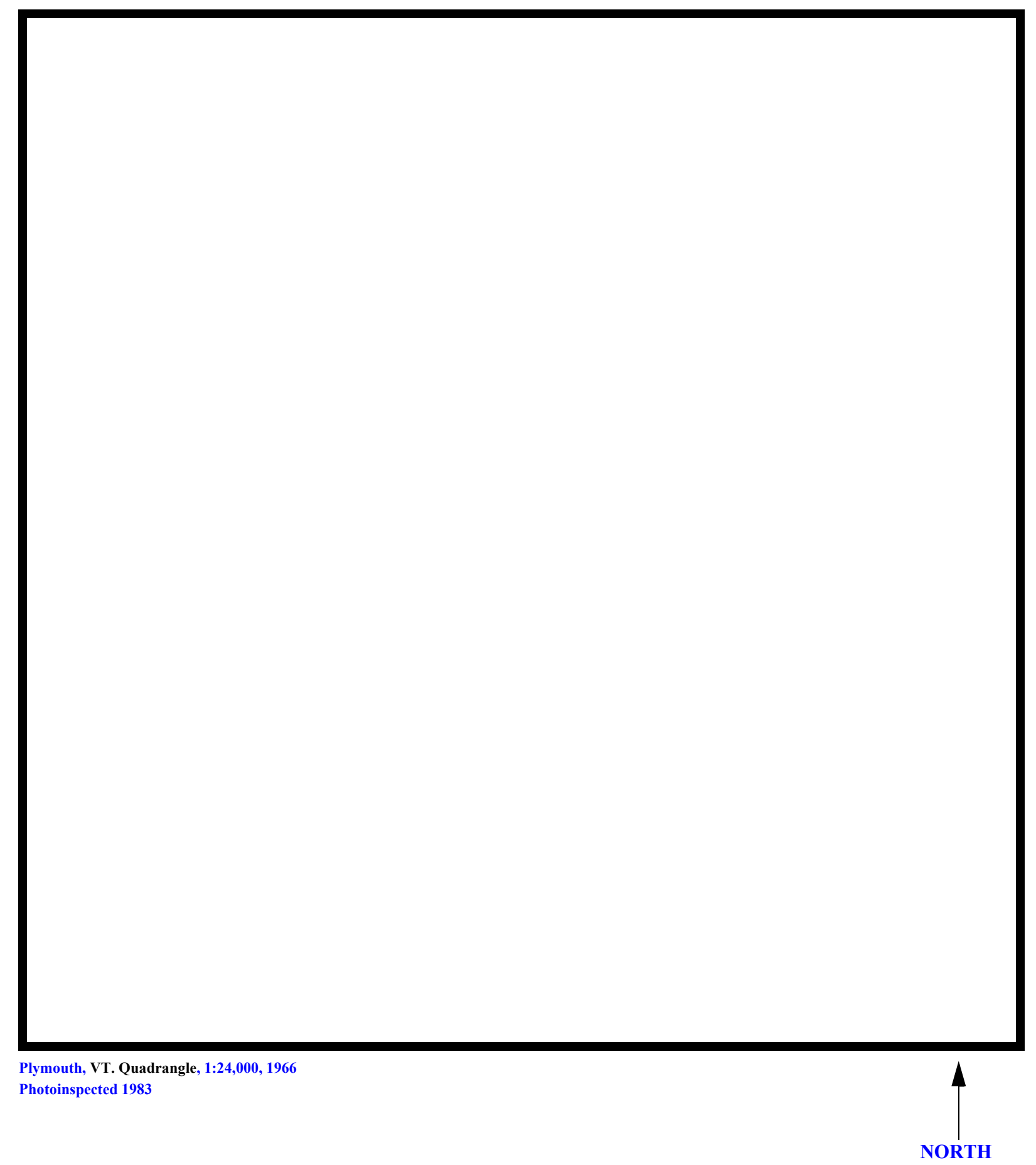

Figure 1. Location of study area on USGS 1:24,000 scale map. 
Figure 2. Location of study area on Vermont Agency of Transportation town highway map. 

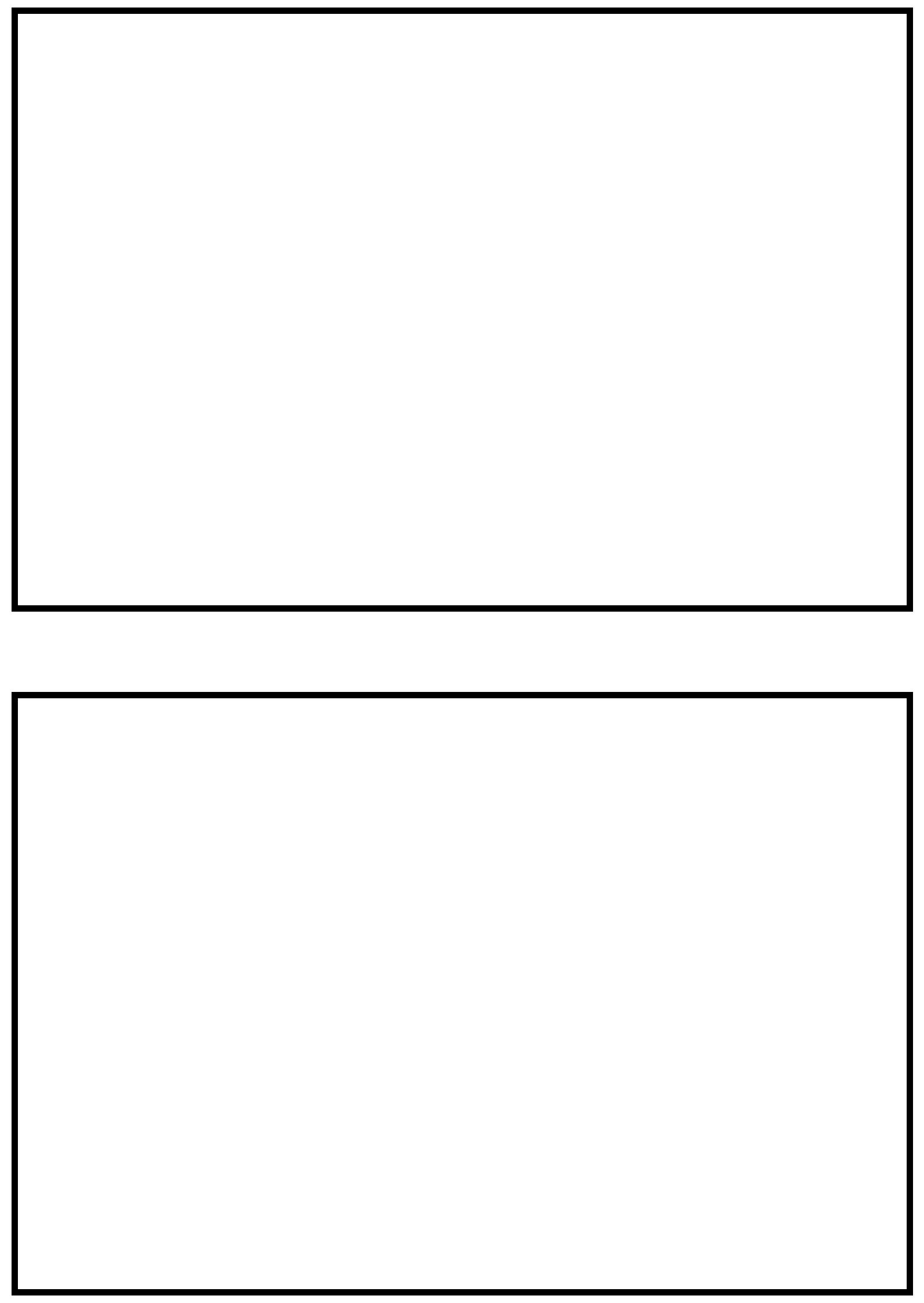

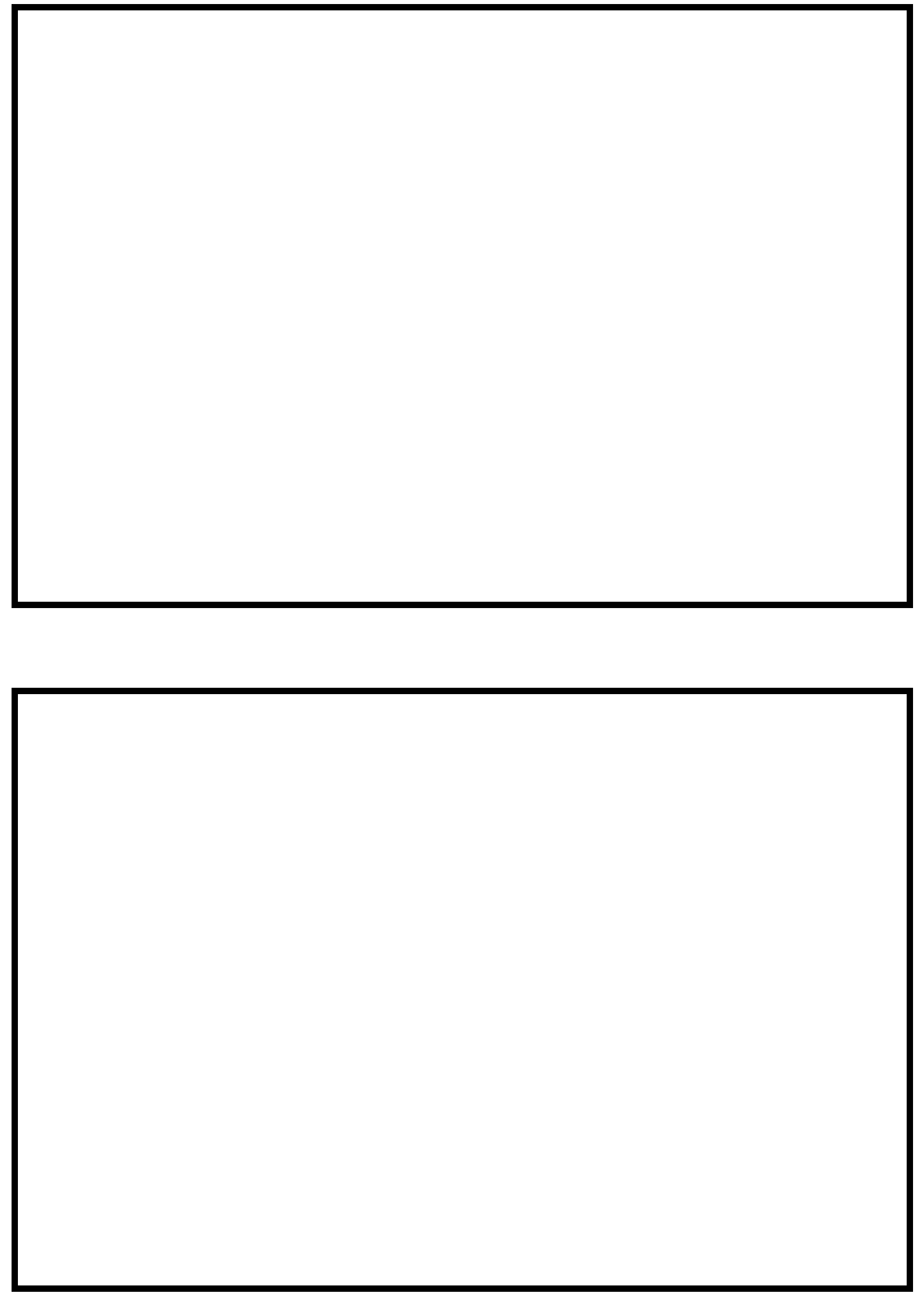


\section{LEVEL II SUMMARY}

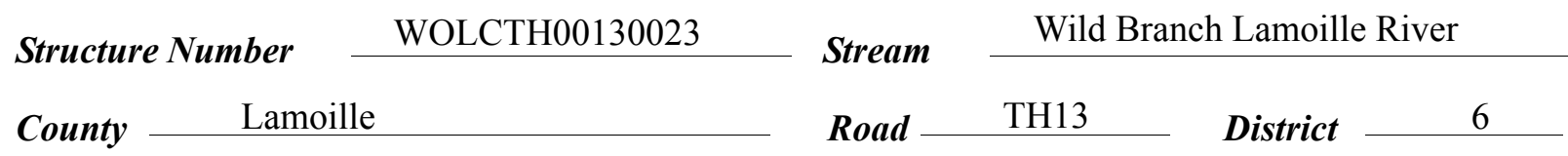

\section{Description of Bridge}

Bridge length $\stackrel{41}{n} \boldsymbol{f t}$ Bridge width $\frac{12.5}{f t}$ Max span length $\stackrel{39}{ } \boldsymbol{f t}$ Alignment of bridge to road (on curve or straight)

Abutment type Vertical, concrete

Stone fill on abutment?

$$
\text { Yes }
$$

\section{Embankment type \\ nato of incnortion} Straight Type-2, around the right wingwalls and right abutment. Type-2, along

-... . . . . .

\section{Yes}

Angle

Is bridge skewed to flood flow according to Yes ' survey?

There is a moderate channel bend in the upstream reach.

Debris accumulation on bridge at time of Level I or Level II site visit:

\begin{tabular}{|c|c|c|c|}
\hline & $\begin{array}{c}\text { Date of incnostion } \\
7 / 17 / 96 \\
\end{array}$ & $\begin{array}{l}\text { Percent of almmant } \\
\text { blocked inortzontatly }\end{array}$ & $\begin{array}{l}\text { Percent of } 0 \text { nel } \\
\text { blocked verticatty }\end{array}$ \\
\hline evel I & $7 / 17 / 96$ & 0 & 0 \\
\hline $\begin{array}{l}\text { Level II } \\
\text { structure. }\end{array}$ & Moderate. & is some debris caught & pstream I-beam of the \\
\hline
\end{tabular}

None. 7/17/96

Doscriho anv, fonturos noar ar at tho hridoo that mav, affort flow, (includo ahsorvation dato) 


\section{Description of the Geomorphic Setting}

General topography The channel is located within a narrow irregular flood plain with steep valley walls along the right side.

Geomorphic conditions at bridge site: downstream (DS), upstream (US)

Date of inspection $\quad 7 / 17 / 96$

DS left: $\quad$ Narrow flood plain to a moderately sloped overbank.

DS right: $\quad$ Steep valley wall.

US left: $\quad$ Narrow flood plain to a moderately sloped overbank.

US right: $\quad$ Narrow flood plain to a steep valley wall.

\section{Description of the Channel}

$\begin{array}{lllll}\text { Average top width } & 65 & \text { Average depth } & \frac{7}{\text { Sand/Cobbles }} \\ \text { Predominant bed material } & \text { Sand / Boulders } & \text { Bank material } & \begin{array}{c}\text { St } \\ \text { Sinuous and laterally }\end{array}\end{array}$

unstable with alluvial channel boundaries and a narrow flood plain."

Vegetative co ${ }^{1}$ Pasture with trees and brush along immediate banks.

DS left: $\quad$ Some brush with Town Highway 1 parallel to channel.

DS right: $\quad$ Brushland with trees along immediate banks.

US left: $\quad$ Short grass and brush with Town Highway 1 parallel to channel.

US right: $\quad$ No

Do banks appear stable? During the 7/17/96 site inspection moderate fluvial erosion and slip failure was noted along the upstream left bank.
date of observatton.

blocks part of the right channel. 7/17/96

Describe any obstructions in channel and date of observation. 


\title{
Hydrology
}

Drainage area $\quad 27.7 \quad \mathrm{mi}^{2}$

Percentage of drainage area in physiographic provinces: (approximate)

Physiographic province/section

New England/Green Mountain
Percent of drainage area 100

\begin{abstract}
Is drainage area considered rural or urban? Rural Describe any significant urbanization:
\end{abstract}

Is there a USGS gage on the stream of interest? $-$

USGS gage description _--

USGS gage number

Gage drainage area $\mathrm{mi}^{2}$

No

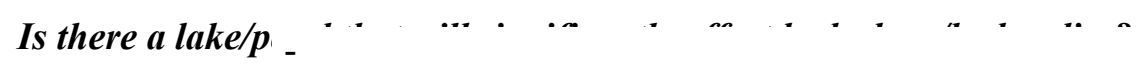

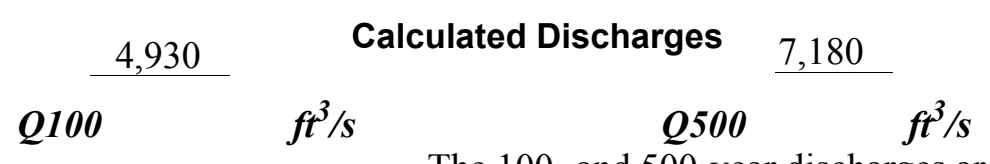

The 100- and 500-year discharges are from the

Flood Insurance Study for the Town of Wolcott (Federal Emergency Management Agency, 1982). 


\section{Description of the Water-Surface Profile Model (WSPRO) Analysis}

Datum for WSPRO analysis (USGS survey, sea level, VTAOT plans)

USGS survey

Datum tie between USGS survey and VTAOT plans

None

Description of reference marks used to determine USGS datum. $\quad$ RM1 is a chiseled X on top of the upstream end of the left abutment (elev. $495.61 \mathrm{ft}$, arbitrary survey datum). RM2 is a chiseled X on top of the upstream end of the upstream right wingwall (elev. $499.27 \mathrm{ft}$, arbitrary survey datum).

\section{Cross-Sections Used in WSPRO Analysis}

\begin{tabular}{|c|c|c|c|}
\hline${ }^{1}$ Cross-section & $\begin{array}{c}\text { Section } \\
\text { Reference } \\
\text { Distance } \\
\text { (SRD) in feet }\end{array}$ & $\begin{array}{c}{ }^{2} \text { Cross-section } \\
\text { development }\end{array}$ & Comments \\
\hline EXITX & -38 & 1 & Exit section \\
\hline FULLV & 0 & 3,5 & $\begin{array}{l}\text { Downstream Full-valley } \\
\text { section (EXITX overbank } \\
\text { and BRIDG channel) }\end{array}$ \\
\hline BRIDG & 0 & 1 & Bridge section \\
\hline RDWAY & 6 & 1 & Road Grade section \\
\hline APTEM & 43 & 1 & $\begin{array}{l}\text { Approach section as } \\
\text { surveyed (Used as a } \\
\text { template) }\end{array}$ \\
\hline APPRO & 50 & 2 & $\begin{array}{l}\text { Modelled Approach sec- } \\
\text { tion (Templated from } \\
\text { APTEM }\end{array}$ \\
\hline
\end{tabular}

${ }^{1}$ For location of cross-sections see plan-view sketch included with Level I field form, Appendix E. For more detail on how cross-sections were developed see WSPRO input file. 


\section{Data and Assumptions Used in WSPRO Model}

Hydraulic analyses of the reach were done by use of the Federal Highway Administration's WSPRO step-backwater computer program (Shearman and others, 1986, and Shearman, 1990). The analyses reported herein reflect conditions existing at the site at the time of the study. Furthermore, in the development of the model it was necessary to assume no accumulation of debris or ice at the site. Results of the hydraulic model are presented in the Bridge Hydraulic Summary, Appendix B, and figure 7.

Channel roughness factors (Manning's " $n$ ") used in the hydraulic model were estimated using field inspections at each cross section following the general guidelines described by Arcement and Schneider (1989). Final adjustments to the values were made during the modelling of the reach. Channel " $\mathrm{n}$ " values for the reach ranged from 0.055 to 0.057 , and overbank " $n$ " values ranged from 0.040 to 0.080 .

Normal depth at the exit section (EXITX) was assumed as the starting water surface. This depth was computed by use of the slope-conveyance method outlined in the user's manual for WSPRO (Shearman, 1990). The slope used was $0.0092 \mathrm{ft} / \mathrm{ft}$, which was estimated from the 100-year water surface slope downstream of the bridge in the Flood Insurance Study for Wolcott, VT (Federal Emergency Management Agency, February 2, 1982).

The surveyed approach section (APTEM) was moved along the approach channel slope $(0.0652 \mathrm{ft} / \mathrm{ft})$ to establish the modelled approach section (APPRO), one bridge length upstream

of the upstream face as recommended by Shearman and others (1986). This location also provides a consistent method for determining scour variables. 


\section{Bridge Hydraulics Summary}

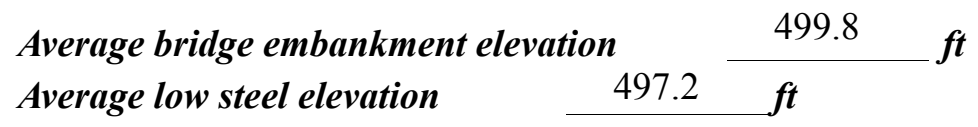

$$
\text { 100-year discharge } \quad 4,930 \quad \mathrm{ft}^{3} / \mathrm{s}
$$

Water-surface elevation in bridge opening $\quad 497.3 \quad f t$

Road overtopping? ___ Y Discharge over road __ $791 \quad \mathrm{ft}^{3} / \mathrm{s}$

Area of flow in bridge opening $\quad 329 \quad \mathrm{ft}^{2}$

Average velocity in bridge opening $12.6 \quad \mathrm{ft} / \mathrm{s}$

$\begin{array}{llll}\text { Maximum WSPRO tube velocity at bridge } & 15.6 \mathrm{ft} / \mathrm{s}\end{array}$

Water-surface elevation at Approach section with bridge $\quad 501.4$

Water-surface elevation at Approach section without bridge $\quad 498.7$

Amount of backwater caused by bridge

$2.7 \quad i$

500-year discharge $\quad 7,180 \quad f^{3} / s$

Water-surface elevation in bridge opening

$497.3 \boldsymbol{f t}$

Road overtopping? ___ Y Discharge over road __ 3,012 $\mathrm{ft}^{3} / \mathrm{s}$

Area of flow in bridge opening $\quad 329 \quad \mathrm{ft}^{2}$

Average velocity in bridge opening $12.7 \mathrm{ft} / \mathrm{s}$

Maximum WSPRO tube velocity at bridge 15.7 's

Water-surface elevation at Approach section with bridge

Water-surface elevation at Approach section without bridge

Amount of backwater caused by bridge 3.1 ,

503.4

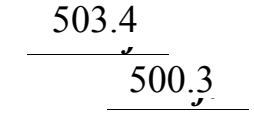

Incipient overtopping discharge $\quad 3,350 \quad \mathrm{ft}^{3} / \mathrm{s}$

Water-surface elevation in bridge opening 495.3 it

Area of flow in bridge opening $\quad 259 \quad \mathrm{ft}^{2}$

Average velocity in bridge opening $\quad 13.0 \mathrm{ft} / \mathrm{s}$

Maximum WSPRO tube velocity at bridge $16.7 \mathrm{ft} / \mathrm{s}$

Water-surface elevation at Approach section with bridge

Water-surface elevation at Approach section without bridge

497.8

Amount of backwater caused by bridge $\quad 0.7$.t 


\section{Scour Analysis Summary}

\section{Special Conditions or Assumptions Made in Scour Analysis}

Scour depths were computed using the general guidelines described in Hydraulic Engineering Circular 18 (Richardson and others, 1995). Scour depths were calculated assuming an infinite depth of erosive material and a homogeneous particle-size distribution. The results of the scour analysis are presented in tables 1 and 2 and a graph of the scour depths is presented in figure 8 .

Contraction scour for the incipient discharge was computed by use of the Laursen's clear-water contraction scour equation (Richardson and others, 1995, p. 32, equation 20). At this site, the 100-year and 500-year discharges resulted in submerged orifice flow. Contraction scour at bridges with orifice flow is best estimated by use of the Chang pressureflow scour equation (oral communication, J. Sterling Jones, October 4, 1996). Thus, contraction scour was computed by use of the Chang equation (Richardson and others, 1995, p. 145-146). Results of this analysis are presented in figure 8 and tables 1 and 2. The streambed armoring depths computed suggest that armoring will not limit the depth of contraction scour. Additional estimates of contraction scour for the 100-year and 500-year discharges were computed by use of Laursen's clear-water scour equation (Richardson and others, 1995, p. 32, equation 20) and the results are presented in Appendix F.

Abutment scour was computed by use of the Froehlich equation (Richardson and others, 1995, p. 48, equation 28). Variables for the Froehlich equation include the Froude number of the flow approaching the embankments, the length of the embankment blocking flow, and the depth of flow approaching the embankment less any roadway overtopping. 


\section{Scour Results}
100-yr discharge 500-yr discharge
Incipient overtopping (Scour depths in feet)

Contraction scour:

Main channel

Live-bed scour

Clear-water scour

Depth to armoring

Left overbank

Right overbank

Local scour:

Abutment scour

11.2

13.29 .1

20.0

Left abutment

22.3

$15.7-$

Right abutment

Pier scour

Pier 1

Pier 2
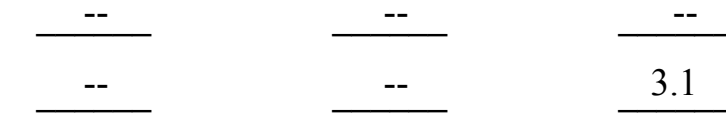

Pier 3

\section{Riprap Sizing}

Abutments:

\section{Left abutment}

\section{Right abutment}

Piers:

Pier 1

Pier 2

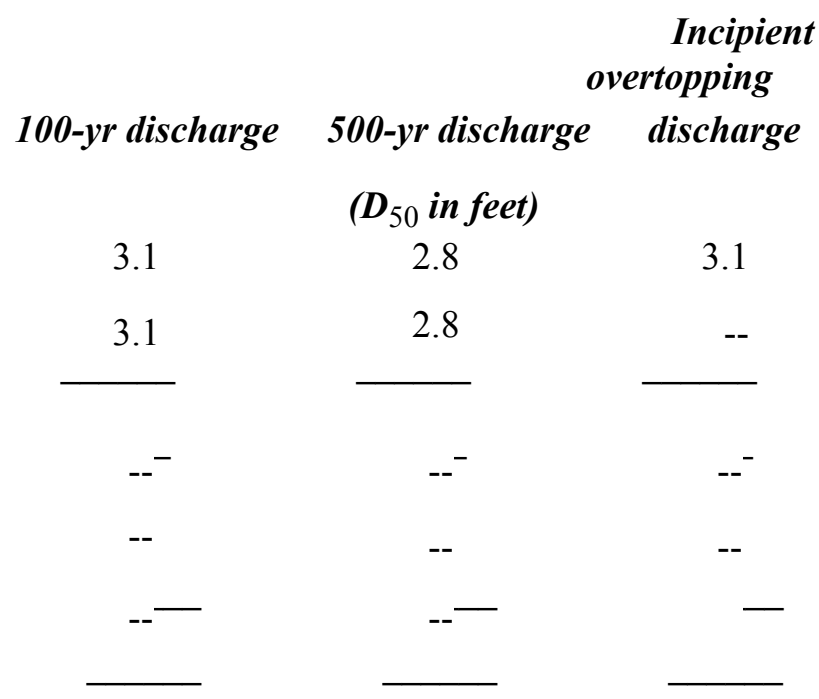




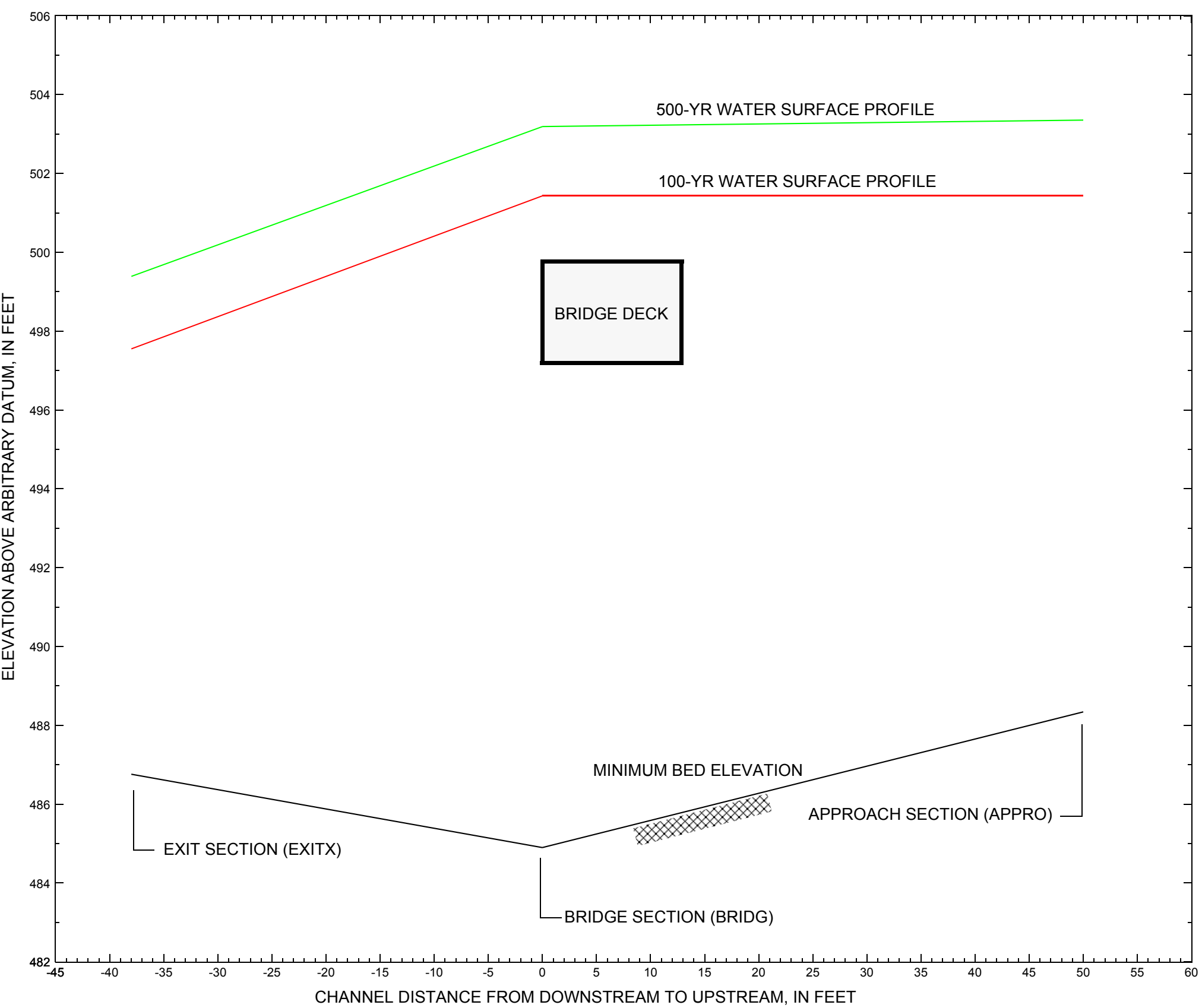

Figure 7. Water-surface profiles for the 100- and 500-yr discharges at structure WOLCTH00130023 on Town Highway 13, crossing the Wild Branch of the Lamoille River, Wolcott, Vermont. 


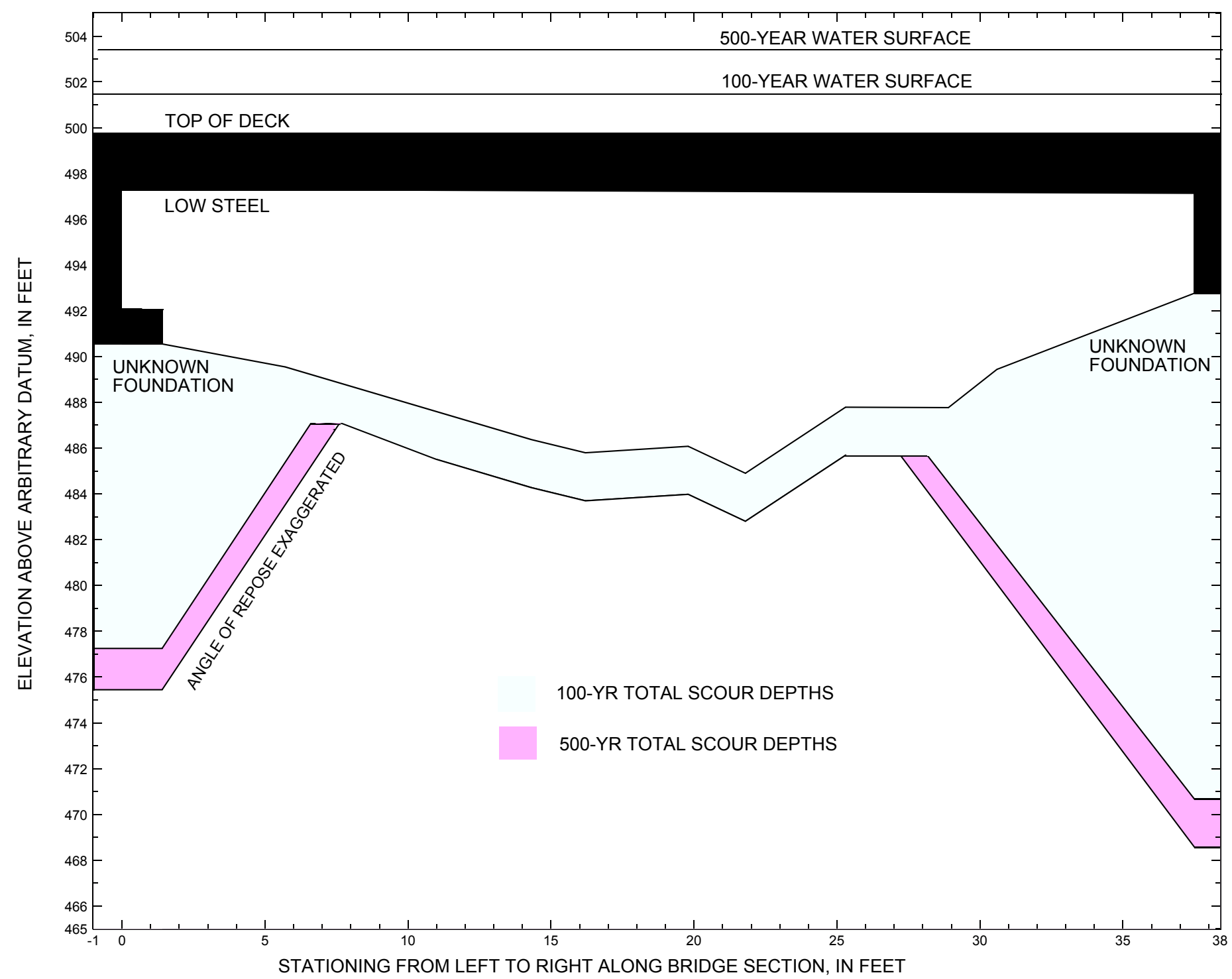

Figure 8. Scour elevations for the 100-yr and 500-yr discharges at structure WOLCTH00130023 on Town Highway 13, crossing the Wild Branch of the Lamoille River, Wolcott, Vermont. 
Table 1. Remaining footing/pile depth at abutments for the 100-year discharge at structure WOLCTH00130023 on Town Highway 13 , crossing the Wild Branch Lamoille River, Wolcott, Vermont.

[VTAOT, Vermont Agency of Transportation; --,no data]

\begin{tabular}{|c|c|c|c|c|c|c|c|c|c|c|c|}
\hline Description & Station $^{1}$ & $\begin{array}{l}\text { VTAOT } \\
\text { minimum } \\
\text { low-chord } \\
\text { elevation } \\
\text { (feet) }\end{array}$ & $\begin{array}{c}\text { Surveyed } \\
\text { minimum } \\
\text { low-chord } \\
\text { elevation }{ }^{2} \\
\text { (feet) }\end{array}$ & $\begin{array}{c}\text { Bottom of } \\
\text { footing } \\
\text { elevation } \\
\text { (feet) }\end{array}$ & $\begin{array}{c}\text { Channel } \\
\text { elevation at } \\
\text { abutment/ } \\
\text { pier }^{2} \\
\text { (feet) }\end{array}$ & $\begin{array}{l}\text { Contraction } \\
\text { scour depth } \\
\text { (feet) }\end{array}$ & $\begin{array}{l}\text { Abutment } \\
\text { scour } \\
\text { depth } \\
\text { (feet) }\end{array}$ & $\begin{array}{l}\text { Pier } \\
\text { scour } \\
\text { depth } \\
\text { (feet) }\end{array}$ & $\begin{array}{l}\text { Depth of } \\
\text { total scour } \\
\text { (feet) }\end{array}$ & $\begin{array}{c}\text { Elevation of } \\
\text { scour }^{2} \\
\text { (feet) }\end{array}$ & $\begin{array}{c}\text { Remaining } \\
\text { footing/pile } \\
\text { depth } \\
\text { (feet) }\end{array}$ \\
\hline \multicolumn{12}{|c|}{100 -yr. discharge is 4,930 cubic-feet per second } \\
\hline Left abutment & 0.0 & -- & 497.3 & -- & 490.6 & 2.1 & 11.2 & -- & 13.3 & 477.3 & -- \\
\hline Right abutment & 37.5 & -- & 497.1 & -- & 492.8 & 2.1 & 20.0 & -- & 22.1 & 470.7 & -- \\
\hline
\end{tabular}

1.Measured along the face of the most constricting side of the bridge.

2.Arbitrary datum for this study.

Table 2. Remaining footing/pile depth at abutments for the 500-year discharge at structure WOLCTH00130023 on Town Highway 13, crossing the Wild Branch Lamoille River, Wolcott, Vermont.

[VTAOT, Vermont Agency of Transportation; --, no data]

\begin{tabular}{|c|c|c|c|c|c|c|c|c|c|c|c|}
\hline Description & Station $^{1}$ & $\begin{array}{l}\text { VTAOT } \\
\text { minimum } \\
\text { low-chord } \\
\text { elevation } \\
\text { (feet) }\end{array}$ & $\begin{array}{l}\text { Surveyed } \\
\text { minimum } \\
\text { low-chord } \\
\text { elevation } \\
\text { (feet) }\end{array}$ & $\begin{array}{l}\text { Bottom of } \\
\text { footing } \\
\text { elevation } \\
\text { (feet) }\end{array}$ & $\begin{array}{c}\text { Channel } \\
\text { elevation at } \\
\text { abutment/ } \\
\text { pier }^{2} \\
\text { (feet) }\end{array}$ & $\begin{array}{l}\text { Contraction } \\
\text { scour depth } \\
\text { (feet) }\end{array}$ & $\begin{array}{l}\text { Abutment } \\
\text { scour } \\
\text { depth } \\
\text { (feet) }\end{array}$ & $\begin{array}{l}\text { Pier } \\
\text { scour } \\
\text { depth } \\
\text { (feet) }\end{array}$ & $\begin{array}{l}\text { Depth of } \\
\text { total scour } \\
\text { (feet) }\end{array}$ & $\begin{array}{c}\text { Elevation of } \\
\text { scour }^{2} \\
\text { (feet) }\end{array}$ & $\begin{array}{c}\text { Remaining } \\
\text { footing/pile } \\
\text { depth } \\
\text { (feet) }\end{array}$ \\
\hline \multicolumn{12}{|c|}{500 -yr. discharge is 7,180 cubic-feet per second } \\
\hline Left abutment & 0.0 & -- & 497.3 & -- & 490.6 & 1.9 & 13.2 & -- & 15.1 & 475.5 & -- \\
\hline Right abutment & 37.5 & -- & 497.1 & -- & 492.8 & 1.9 & 22.3 & -- & 24.2 & 468.6 & -- \\
\hline
\end{tabular}

1.Measured along the face of the most constricting side of the bridge.

2.Arbitrary datum for this study. 


\section{SELECTED REFERENCES}

Arcement, G.J., Jr., and Schneider, V.R., 1989, Guide for selecting Manning's roughness coefficients for natural channels and flood plains:

U.S. Geological Survey Water-Supply Paper 2339, 38 p.

Barnes, H.H., Jr., 1967, Roughness characteristics of natural channels: U.S. Geological Survey Water-Supply Paper 1849,213 p.

Benson, M. A., 1962, Factors Influencing the Occurrence of Floods in a Humid Region of Diverse Terrain: U.S. Geological Survey Water-Supply Paper 1580-B, 64 p.

Brown, S.A. and Clyde, E.S., 1989, Design of riprap revetment: Federal Highway Administration Hydraulic Engineering Circular No. 11, Publication FHWA-IP-89-016, 156 p.

Federal Highway Administration, 1983, Runoff estimates for small watersheds and development of sound design: Federal Highway Administration Report FHWA-RD-77-158.

Federal Highway Administration, 1993, Stream Stability and Scour at Highway Bridges: Participant Workbook: Federal Highway Administration Report FHWA-HI-91-011.

Federal Emergency Management Agency, 1982, Flood Insurance Study, Town of Wolcott, Lamoille County, Vermont: Washington, D.C., February 2, 1982.

Froehlich, D.C., 1989, Local scour at bridge abutments in Ports, M.A., ed., Hydraulic Engineering--Proceedings of the 1989 National Conference on Hydraulic Engineering: New York, American Society of Civil Engineers, p. 13-18.

Hayes, D.C.,1993, Site selection and collection of bridge-scour data in Delaware, Maryland, and Virginia: U.S. Geological Survey WaterResources Investigation Report 93-4017, 23 p.

Interagency Advisory Committee on Water Data, 1982, Guidelines for determining flood flow frequency: U.S. Geological Survey, Bulletin 17B of the Hydrology Subcommittee, 190 p.

Johnson, C.G. and Tasker, G.D.,1974, Progress report on flood magnitude and frequency of Vermont streams: U.S. Geological Survey Open-File Report 74-130, 37 p.

Lagasse, P.F., Schall, J.D., Johnson, F., Richardson, E.V., Chang, F., 1995, Stream Stability at Highway Structures: Federal Highway Administration Hydraulic Engineering Circular No. 20, Publication FHWA-IP-90-014, 144 p.

Laursen, E.M., 1960, Scour at bridge crossings: Journal of the Hydraulics Division, American Society of Civil Engineers, v. 86, no. HY2, p. 39-53.

Potter, W. D., 1957a, Peak rates of runoff in the Adirondack, White Mountains, and Maine woods area, Bureau of Public Roads

Potter, W. D., 1957b, Peak rates of runoff in the New England Hill and Lowland area, Bureau of Public Roads

Richardson, E.V. and Davis, S.R., 1995, Evaluating scour at bridges: Federal Highway Administration Hydraulic Engineering Circular No. 18, Publication FHWA-IP-90-017, 204 p.

Richardson, E.V., Simons, D.B., and Julien, P.Y., 1990, Highways in the river environment: Federal Highway Administration Publication FHWA-HI-90-016.

Ritter, D.F., 1984, Process Geomorphology: W.C. Brown Co., Debuque, Iowa, 603 p.

Shearman, J.O., 1990, User's manual for WSPRO--a computer model for water surface profile computations: Federal Highway Administration Publication FHWA-IP-89-027, 187 p.

Shearman, J.O., Kirby, W.H., Schneider, V.R., and Flippo, H.N., 1986, Bridge waterways analysis model; research report: Federal Highway Administration Publication FHWA-RD-86-108, 112 p.

Talbot, A.N., 1887, The determination of water-way for bridges and culverts.

U.S. Department of Transportation, 1993, Stream stability and scour at highway bridges, Participant Workbook: Federal Highway Administration Publication FHWA HI-91-011.

U.S. Geological Survey, 1986, Wolcott, Vermont 7.5 Minute Series quadrangle map: U.S. Geological Survey Topographic Maps, Scale 1:24,000. 


\section{APPENDIX A: \\ WSPRO INPUT FILE}




\section{WSPRO INPUT FILE}

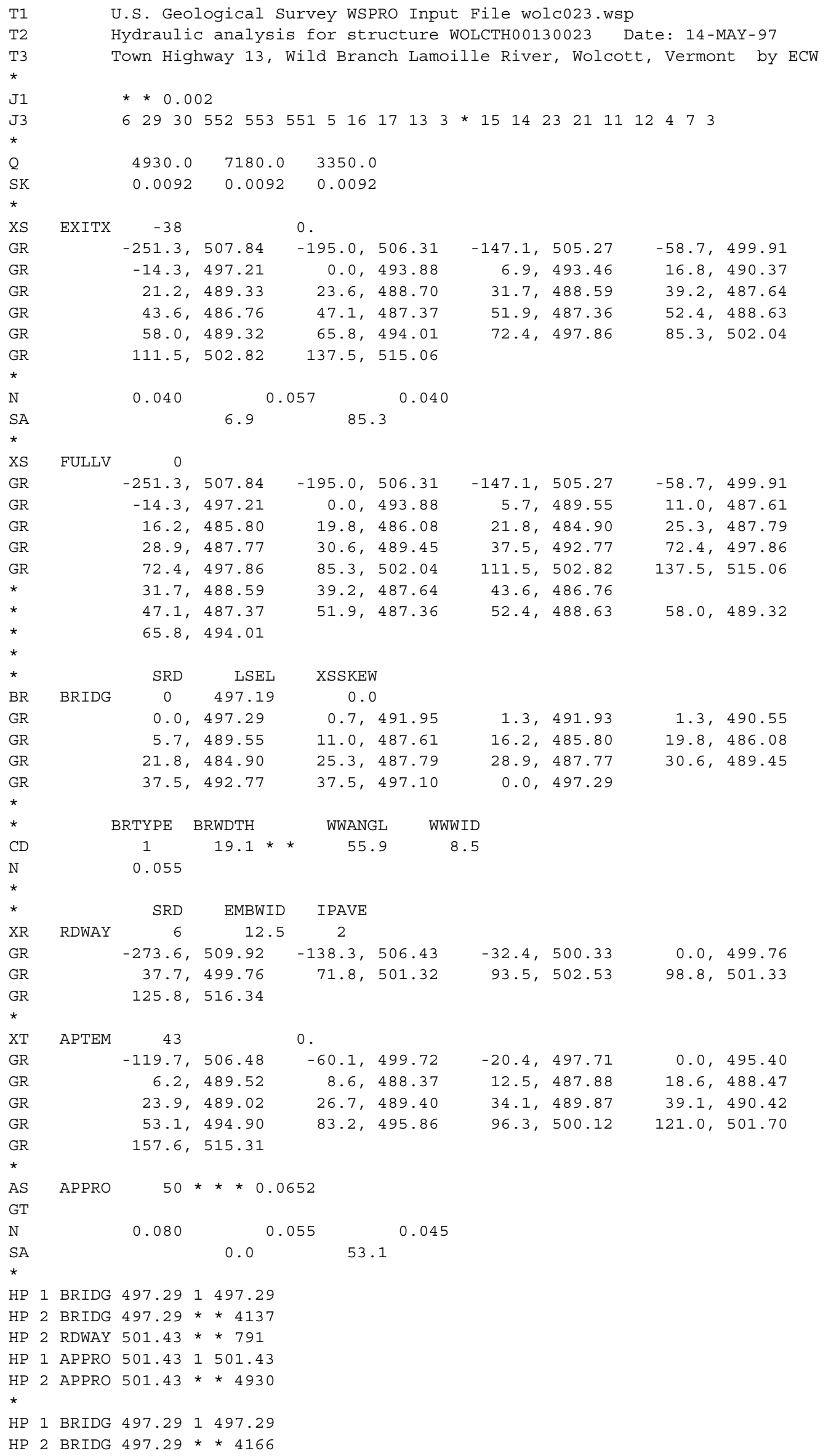




\section{APPENDIX B: \\ WSPRO OUTPUT FILE}


WSPRO OUTPUT FILE

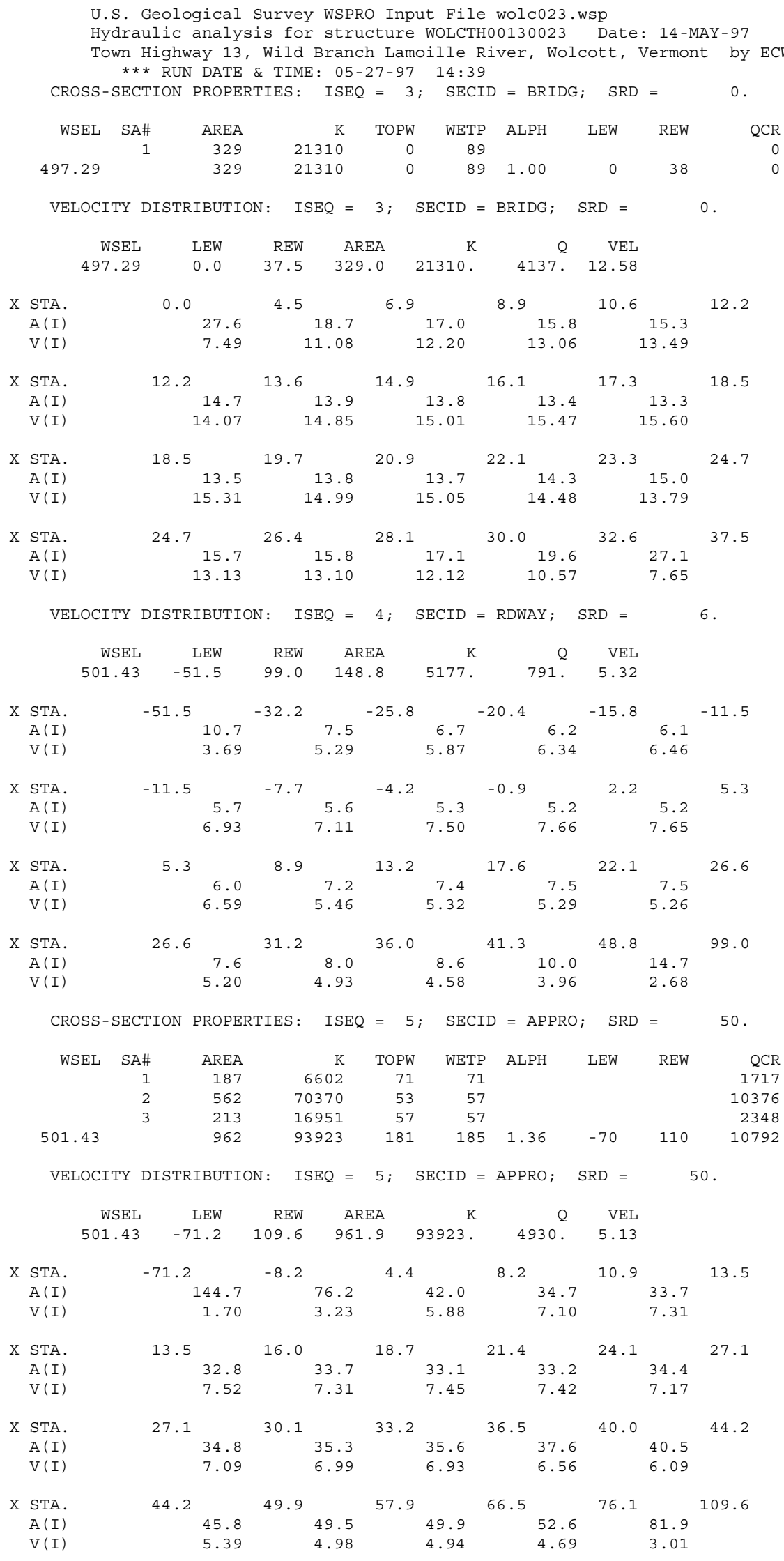


WSPRO OUTPUT FILE (continued)

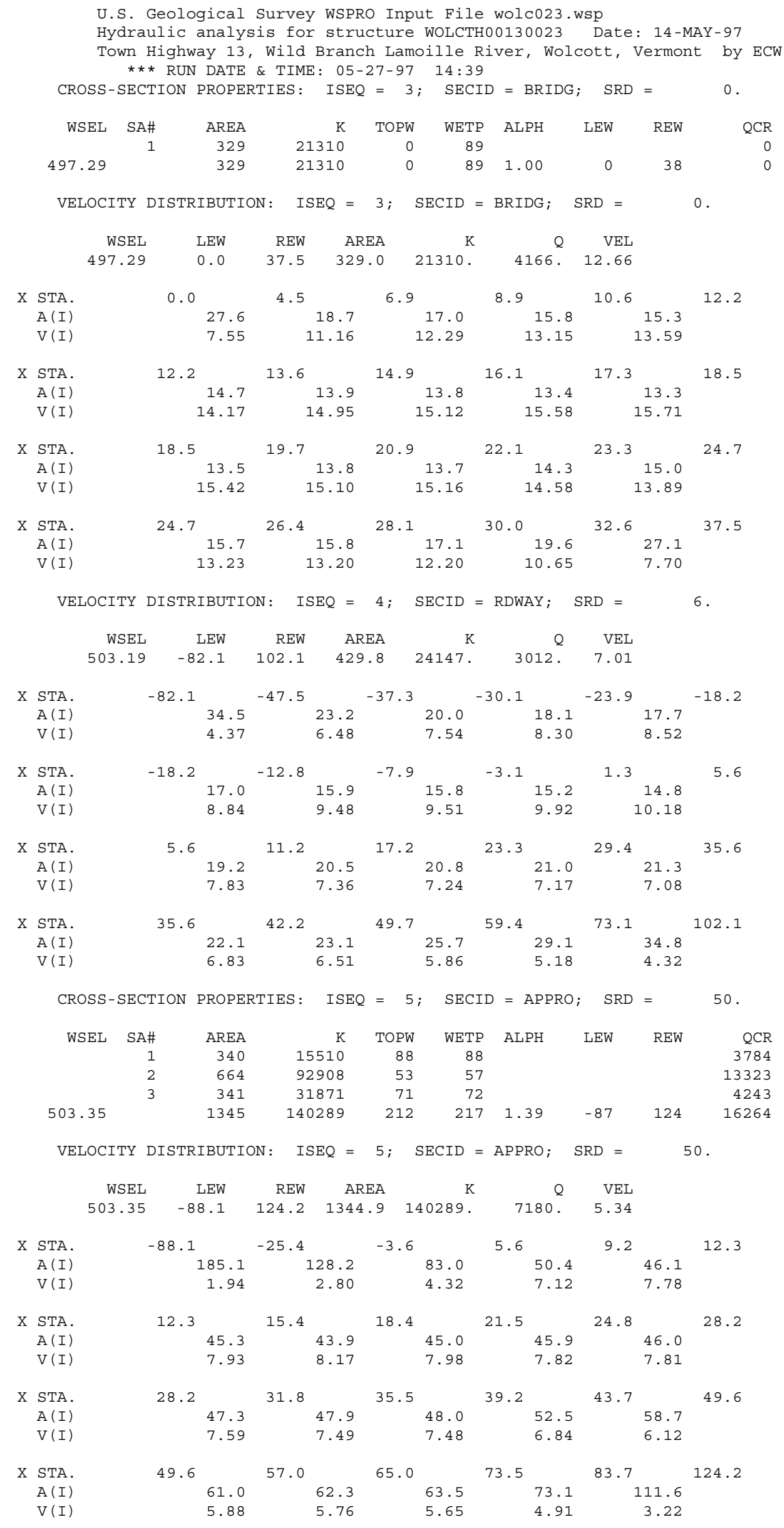


WSPRO OUTPUT FILE (continued)

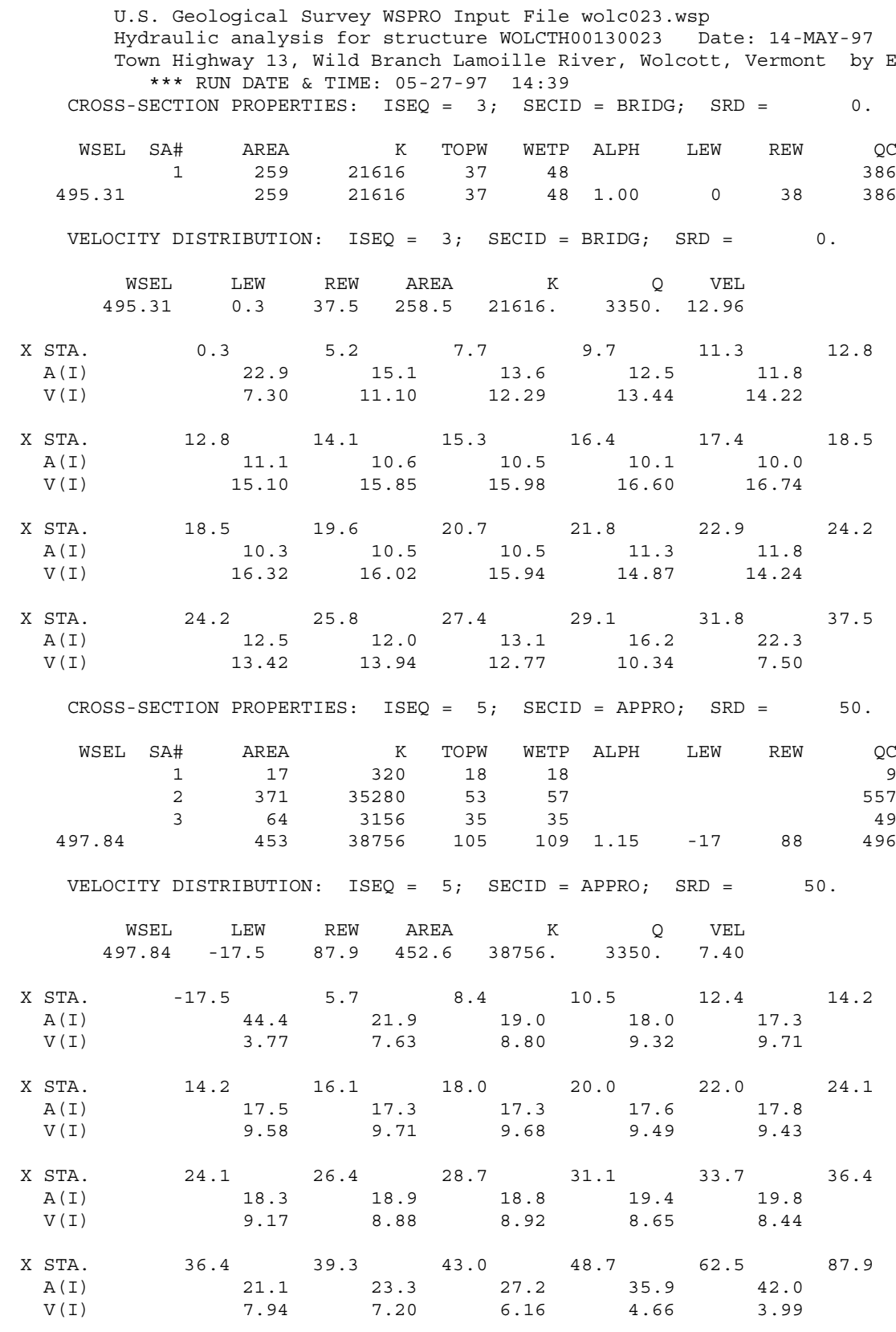


WSPRO OUTPUT FILE (continued)

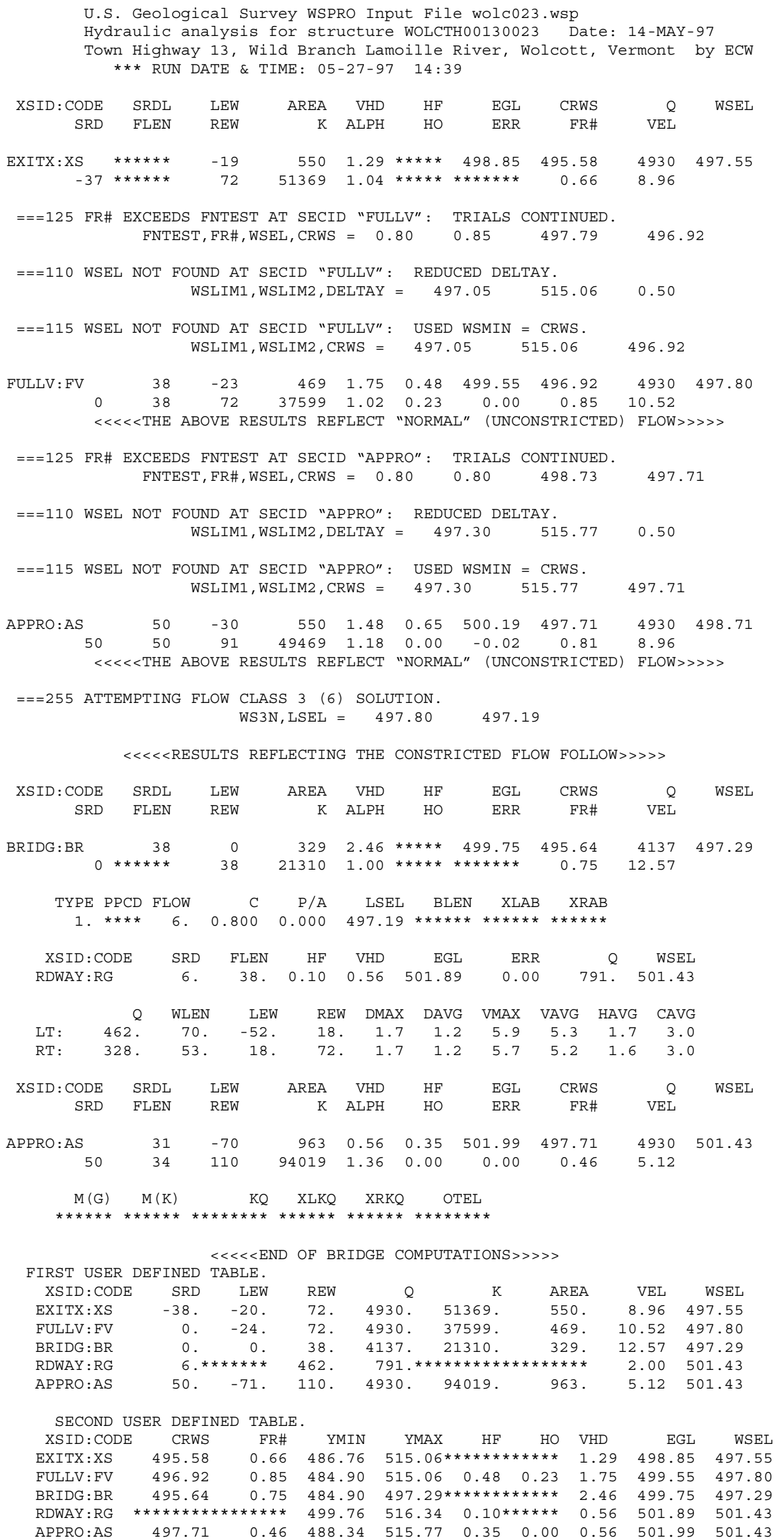


WSPRO OUTPUT FILE (continued)

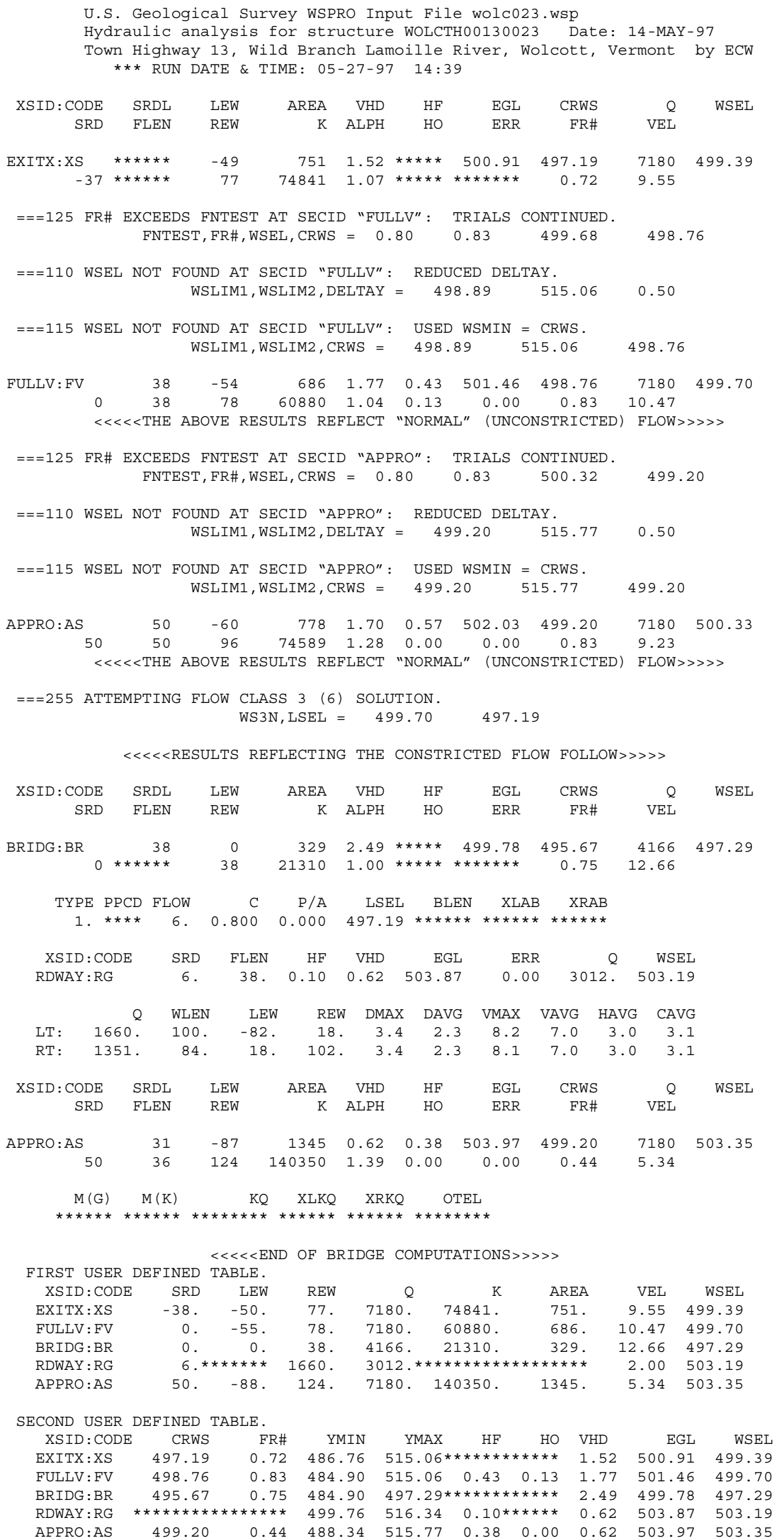


WSPRO OUTPUT FILE (continued)

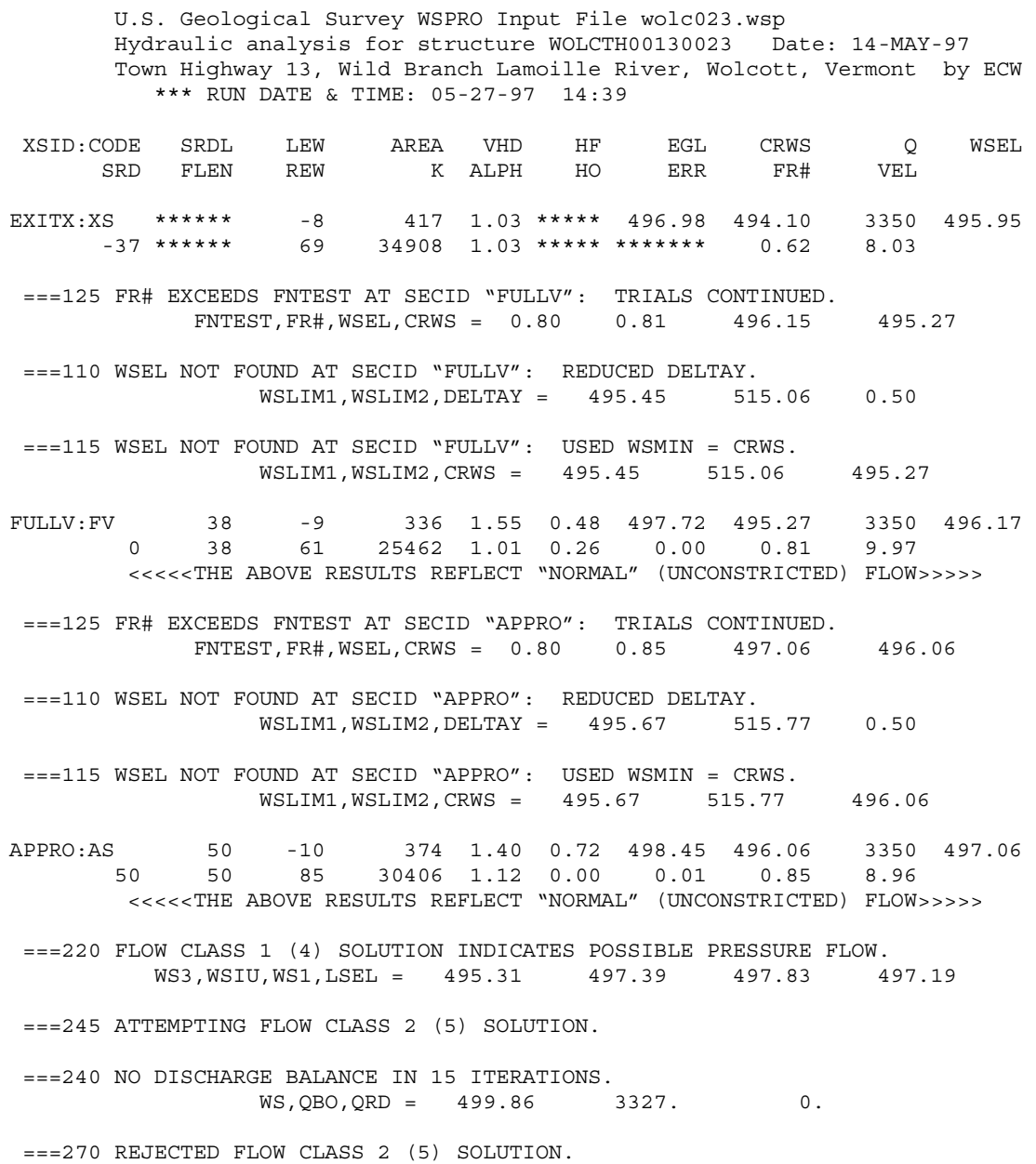




\section{APPENDIX C:}

\section{BED-MATERIAL PARTICLE-SIZE DISTRIBUTION}




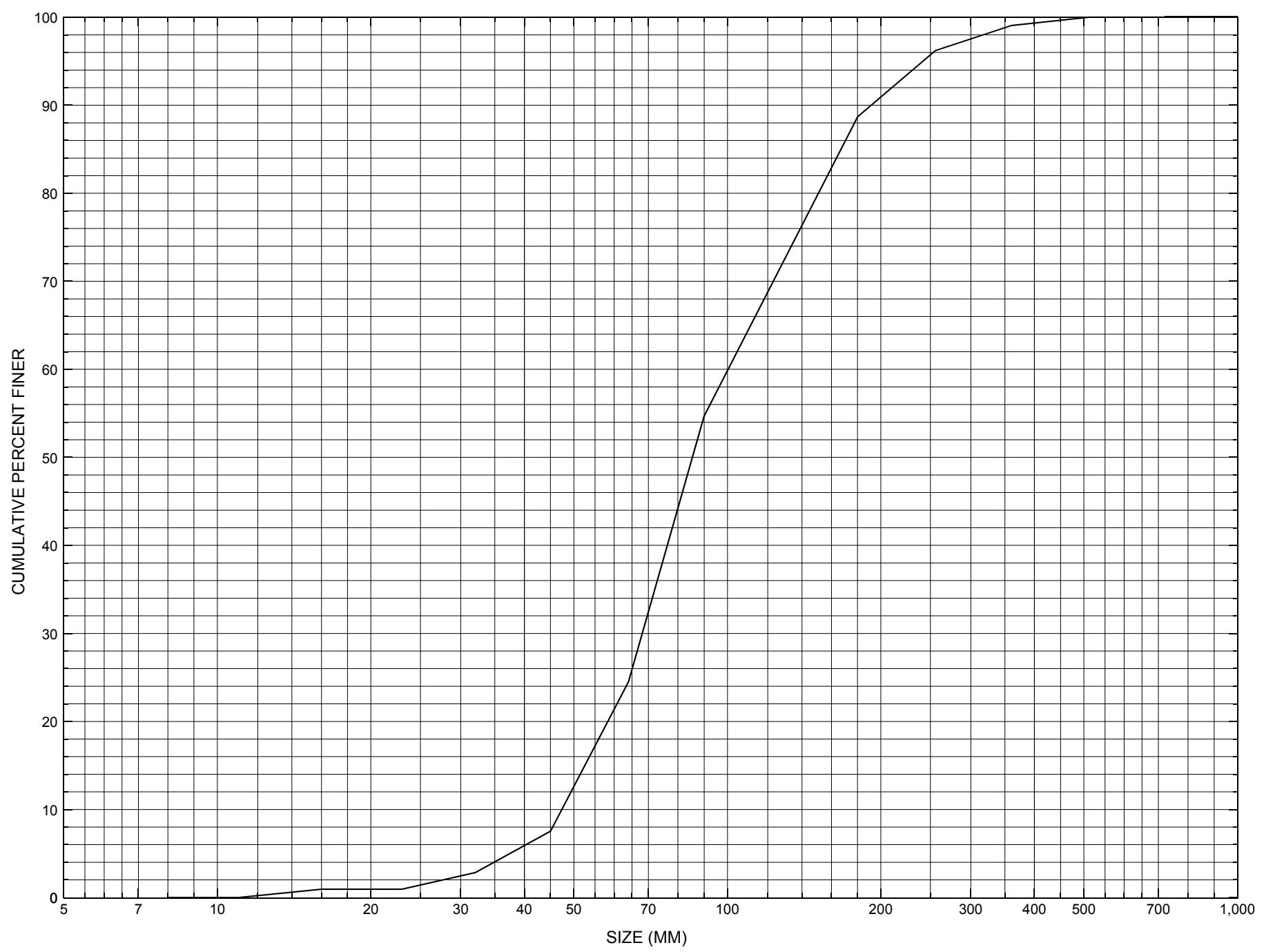

Appendix C. Bed material particle-size distribution for a pebble count in the channel approach of structure WOLCTH00130023, in Wolcott, Vermont. 


\section{APPENDIX D: \\ HISTORICAL DATA FORM}




\section{Structure Number WOLCTH00130023}

\section{General Location Descriptive}

Data collected by (First Initial, Full last name) $\underline{\mathbf{L}}$. Medalie

Date $(M M / D D / Y Y) \_10 / 13 / \underline{95}$

Highway District Number (I - 2; nn) $\mathbf{0 6}$

Town (FIPS place code; I - 4; nnnnn) $\mathbf{8 5 3 7 5}$

Waterway (I - 6) Wild Branch Lamoille River

Route Number TH 13

Topographic Map Wolcott

Latitude (I - 16; nnnn.n) 44359
County (FIPS county code; I - 3; nnn)

Mile marker (I - 11; nnn.nnn) $\mathbf{0 0 0 0 0 0}$

Road Name (I - 7): -

Vicinity (I - 9)

Hydrologic Unit Code: 2010005

Longitude (i - 17; nnnnn.n) $\mathbf{7 2 2 8 0}$

\section{Select Federal Inventory Codes}

FHWA Structure Number (I - 8) $\mathbf{1 0 0 8 1 0 0 0 2 3 0 8 1 0}$

Maintenance responsibility $(I-21 ; n n) \quad \mathbf{0 3} \quad$ Maximum span length $(I-48 ; n n n n) \underline{\mathbf{0 0 3 9}}$

Year built (I - 27; YYYY) 1928

Structure length (I - 49; nnnnnn) $\underline{\mathbf{0 0 0 0 4 1}}$

Average daily traffic, ADT (I - 29; nnnnnn) $\underline{000010}$ Deck Width (I-52; nn.n) 125

Year of ADT (I - 30; YY) $\mathbf{9 3}$

Channel \& Protection $(I-61 ; n) \underline{\mathbf{5}}$

Opening skew to Roadway $(I-34 ; n n) \quad \mathbf{0 0}$

Waterway adequacy $(I-71 ; n) \quad 5$

Operational status $(I-41 ; X) \underline{P}$

Underwater Inspection Frequency $(I-92 B ; X Y Y) \_\mathbf{N}$

Structure type (I - 43; nnn) $\mathbf{3 0 3}$

Year Reconstructed (I - 106) 1973

Approach span structure type $(I-44 ; n n n) \quad \mathbf{0 0 0}$

Clear span (nnn.n ft)

Number of spans (I - 45; nnn) $\underline{\mathbf{0 0 1}}$

Vertical clearance from streambed ( $n n n . n \mathrm{ft}$ )

Number of approach spans (I - 46; nnnn) $\mathbf{0 0 0 0}$ Waterway of full opening (nnn.n $\left.\mathrm{ft}^{2}\right)$

Comments:

According to the structural inspection report dated 6/26/95, the deck of the structure consists of wood planks with wood runners. The posts and rails are iron, which is rusted. The right abutment and its wingwalls are concrete with a small concrete footing. There is a fine vertical crack and small leak under the right side (upstream) girder. The left abument appears to be a concrete faced, laid-up stone wall with a concrete footing and laid-up stone wingwalls. Boulder riprap has been placed in front of both abutments and their wingwalls. The US channel flows toward the bridge at nearly 45 degrees. A large, coarse gravel bar in the US channel along the right abutment. Boulders and (Continued, page 33) 


\section{Bridge Hydrologic Data}

Is there hydrologic data available? $\underline{\mathbf{N}}$ if No, type ctrl-n $h \quad$ VTAOT Drainage area $\left(m i^{2}\right)$ : -

Terrain character:

Stream character \& type: -

Streambed material:

Discharge Data (cfs):

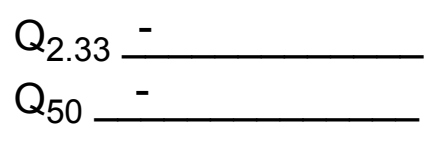

Record flood date $(M M / D D / Y Y):-{ }^{\prime}-$
Estimated Discharge $(c f s):-$

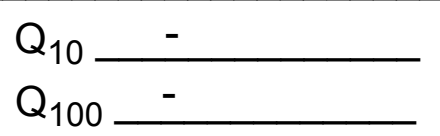

$\mathrm{Q}_{25}$

Water surface elevation $(f t):-$ $(\mathrm{ft} / \mathrm{s}):$

Ice conditions (Heavy, Moderate, Light) : -

Debris (Heavy, Moderate, Light):

The stage increases to maximum highwater elevation (Rapidly, Not rapidly):

The stream response is (Flashy, Not flashy):

Describe any significant site conditions upstream or downstream that may influence the stream's stage: -

Watershed storage area (in percent):

The watershed storage area is: - (1-mainly at the headwaters; 2- uniformly distributed; 3-immediatly upstream oi the site)

Water Surface Elevation Estimates for Existing Structure:

\begin{tabular}{|l|l|l|l|l|l|}
\hline Peak discharge frequency & $Q_{2.33}$ & $Q_{10}$ & $Q_{25}$ & $Q_{50}$ & $Q_{100}$ \\
Water surface elevation (ft)) & - & - & - & - & - \\
Velocity (ft/sec) & - & - & - & - & - \\
\hline
\end{tabular}

Long term stream bed changes: -

Is the roadway overtopped below the $\mathrm{Q}_{100}$ ? (Yes, No, Unknown): $\mathbf{U}$ Frequency: -

Relief Elevation $(f t)$ :

Discharge over roadway at $Q_{100}\left(f t^{3} / \mathrm{sec}\right)$ :

Are there other structures nearby? (Yes, No, Unknown): Upstream distance (miles): Town: If No or Unknown, type ctrl-n os Highway No. :Structure No. : Year Built:

Clear span (ft): Clear Height $(f t)$ : Full Waterway $\left(f^{2}\right)$ : 
Downstream distance (miles): Town: Year Built:

Highway No. : Structure No. : Structure Type:

Clear span (ft): Clear Height $(f t)$ : Full Waterway $\left(f^{2}\right)$ : -

Comments:

possibly ledge outcrops, with small areas of erosion along the US and DS road embankments.

\section{USGS Watershed Data}

Watershed Hydrographic Data

Drainage area (DA) $27.745 \mathrm{mi}^{2}$

Lake/pond/swamp area

0.265 $\mathrm{mi}^{2}$

Watershed storage (ST)

Bridge site elevation 770.8 0.955 $\%$

Main channel length 11.526 $\mathrm{ft}$

Headwater elevation 2617 $\mathrm{ft}$ $10 \%$ channel length elevation $\mathrm{mi}$

Main channel slope

(S) 86.51 816.72 $\mathrm{ft} \quad 85 \%$ channel length elevation $\mathrm{ft}$

Watershed Precipitation Data

Average site precipitation in Average headwater precipitation in

Maximum 2yr-24hr precipitation event $(124,2)$ in

Average seasonal snowfall (Sn) $\mathrm{ft}$ 


\section{Bridge Plan Data}

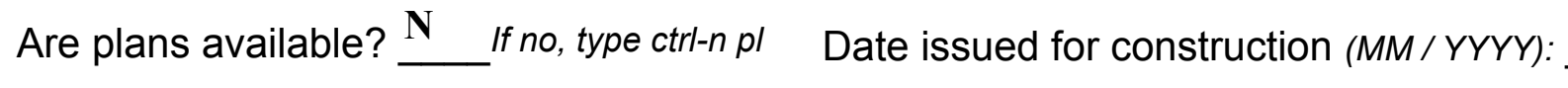

Project Number

Minimum channel bed elevation:

Low superstructure elevation: USLAB DSLAB USRAB DSRAB Benchmark location description:

NO BENCKMARK INFORMATION

Reference Point (MSL, Arbitrary, Other): Datum (NAD27, NAD83, Other):

Foundation Type: 4

If 1 : Footing Thickness

If 2: Pile Type:

If 3: Footing bottom elevation:

Is boring information available? $\mathbf{N}$

Foundation Material Type: $\mathbf{3}$

(1-Spreadfooting; 2-Pile; 3- Gravity; 4-Unknown)

Footing bottom elevation: -

Briefly describe material at foundation bottom elevation or around piles:

NO DRILL BORING INFORMATION

Comments: 


\section{Cross-sectional Data}

Is cross-sectional data available? $\underline{\mathbf{Y}}$

If no, type ctrl-n xs

Source (FEMA, VTAOT, Other)? VTAOT

This is a cross-section of the upstream face. The low cord elevation is from the survey log

Comments: done for this report on $07 / 17 / 96$. The low cord to bed length data is from the sketch attached

to a bridge inspection report dated $06 / 26 / 95$. The sketch was done on 10/20/93.

\begin{tabular}{|l|l|l|l|l|l|l|l|l|l|l|l|}
\hline Station & $\mathbf{0}$ & $\mathbf{1 2 . 3}$ & $\mathbf{1 9 . 3}$ & $\mathbf{2 8 . 3}$ & $\mathbf{3 7 . 3}$ & - & - & - & - & - & - \\
\hline Feature & LAB & - & - & - & RAB & - & - & - & - & - & - \\
\hline $\begin{array}{l}\text { Low cord } \\
\text { elevation }\end{array}$ & $\mathbf{4 9 7 . 3}$ & - & - & - & $\mathbf{4 9 7 . 1}$ & - & - & - & - & - & - \\
\hline $\begin{array}{l}\text { Bed } \\
\text { elevation }\end{array}$ & 491.7 & - & - & - & 493.1 & - & - & - & - & - & - \\
\hline $\begin{array}{l}\text { Low cord to } \\
\text { bed length }\end{array}$ & $\mathbf{5 . 6}$ & $\mathbf{1 0 . 5}$ & $\mathbf{1 1 . 9}$ & $\mathbf{9 . 1}$ & $\mathbf{4 . 0}$ & - & - & - & - & - & - \\
\hline Station & - & - & - & - & - & - & - & - & - & - & - \\
\hline Feature & - & - & - & - & - & - & - & - & - & - & - \\
\hline $\begin{array}{l}\text { Low cord } \\
\text { elevation }\end{array}$ & - & - & - & - & - & - & - & - & - & - & - \\
\hline $\begin{array}{l}\text { Bed } \\
\text { elevation }\end{array}$ & - & - & - & - & - & - & - & - & - & - & - \\
\hline $\begin{array}{l}\text { Low cord to } \\
\text { bed length }\end{array}$ & - & - & - & - & - & - & - & - & - & - & - \\
\hline
\end{tabular}

Source (FEMA, VTAOT, Other)?

Comments:

\begin{tabular}{|l|l|l|l|l|l|l|l|l|l|l|l|}
\hline Station & - & - & - & - & - & - & - & - & - & - & - \\
\hline Feature & - & - & - & - & - & - & - & - & - & - & - \\
\hline $\begin{array}{l}\text { Low cord } \\
\text { elevation }\end{array}$ & - & - & - & - & - & - & - & - & - & - & - \\
\hline $\begin{array}{l}\text { Bed } \\
\text { elevation }\end{array}$ & - & - & - & - & - & - & - & - & - & - & - \\
\hline $\begin{array}{l}\text { Low cord to } \\
\text { bed length }\end{array}$ & - & - & - & - & - & - & - & - & - & - & - \\
\hline Station & - & - & - & - & - & - & - & - & - & - & - \\
\hline Feature & - & - & - & - & - & - & - & - & - & - & - \\
\hline $\begin{array}{l}\text { Low cord } \\
\text { elevation }\end{array}$ & - & - & - & - & - & - & - & - & - & - & - \\
\hline $\begin{array}{l}\text { Bed } \\
\text { elevation }\end{array}$ & - & - & - & - & - & - & - & - & - & - & - \\
\hline $\begin{array}{l}\text { Low cord to } \\
\text { bed length }\end{array}$ & - & - & - & - & - & - & - & - & - & - & - \\
\hline
\end{tabular}




\section{APPENDIX E: \\ LEVEL I DATA FORM}


U. S. Geological Survey

Bridge Field Data Collection and Processing Form

Qa/Qc Check by: EW Date: 8 /14/96

\section{Structure Number WOLCTH00130023} Computerized by: $\underline{\mathbf{E W}}$ Date: $\underline{\mathbf{8} / \mathbf{1 4} / 96}$

Reviewd by: $\quad$ EW Date: $\underline{\mathbf{5} / \mathbf{2 8} / \mathbf{9 7}}$

\section{A. General Location Descriptive}

1. Data collected by (First Initial, Full last name) $\mathbf{J}$. DEGNAN

2. Highway District Number 06

Mile marker $\mathbf{0 0 0 0 0 0}$

County Lamoille (015)

Town WOLCOTT (85375)

Waterway (l - 6)WILD BRANCH LAMOILLE RIVER

Route Number $\mathbf{C 3 0 1 3}$

Road Name -

Hydrologic Unit Code: 2010005

3. Descriptive comments:

This structure has a wooden deck with steel I-beams. The bridge is located 0.01 miles to the junction with CI2 TH1.

\section{B. Bridge Deck Observations}
4. Surface cover... LBUS 5
RBUS 4
LBDS 4
RBDS 6
Overall 5

(2b us, ds,lb,rb: 1- Urban; 2- Suburban; 3- Row crops; 4- Pasture; 5- Shrub- and brushland; 6- Forest; 7- Wetland)
5. Ambient water surface... US 2
UB 2
DS 2
(1- pool; 2- riffle)

6. Bridge structure type 1 (1- single span; 2- multiple span; 3- single arch; 4- multiple arch; 5-cylindrical culvert; 6- box culvert; or 7- other)
7. Bridge length 41
(feet)
Span length $\underline{39}$
(feet)
Bridge width 12.5 (feet)

\section{Road approach to bridge:}
8. LB 2
RB 2
( 0 even, 1- lower, 2- higher)
9. LB_
RB $\underline{2}$
(1-Paved, 2- Not paved)

10. Embankment slope (run / rise in feet / foot)

US left

US right

\begin{tabular}{|c|c|c|c|}
\hline \multicolumn{2}{|c|}{ Protection } & \multirow{2}{*}{ 13.Erosion } & 14.Severity \\
\hline 11.Type & 12.Cond. & & \\
\hline $\mathbf{0}$ & - & $\mathbf{0}$ & - \\
\hline
\end{tabular}

LBUS

RBUS

RBDS

LBDS

\begin{tabular}{l|l}
$\mathbf{0}$ & - \\
$\mathbf{0}$ & - \\
\hline $\mathbf{0}$ & - \\
\hline $\mathbf{0}$ & - \\
\hline
\end{tabular}

\begin{tabular}{l|l}
\hline $\mathbf{0}$ & - \\
\hline $\mathbf{0}$ & - \\
\hline $\mathbf{0}$ & - \\
\hline
\end{tabular}

Bank protection types: 0 - none; 1- $<12$ inches;

2- $<36$ inches; 3- $<48$ inches;

4- < 60 inches; 5- wall / artificial levee

Bank protection conditions: 1- good; 2- slumped;

3- eroded; 4- failed

Erosion: 0 - none; 1- channel erosion; 2 -

road wash; 3- both; 4- other

Erosion Severity: 0 - none; 1- slight; 2- moderate; 3- severe

\section{Channel approach to bridge (BF):}

15. Angle of approach: $\mathbf{4 5}$

16. Bridge skew: 45

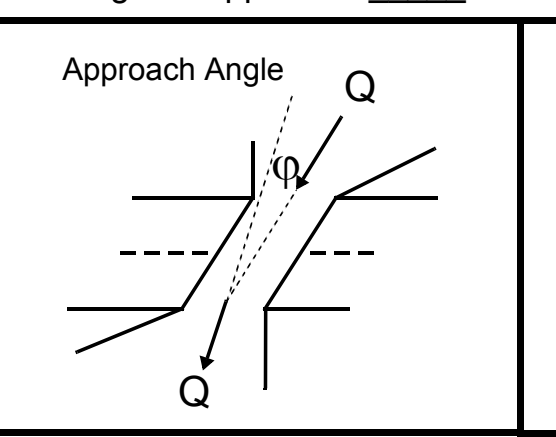

17. Channel impact zone 1 :

Where? LB (LB, RB)

Exist? $\underline{Y}(Y \circ$ or $N)$ Bridge Skew Angle

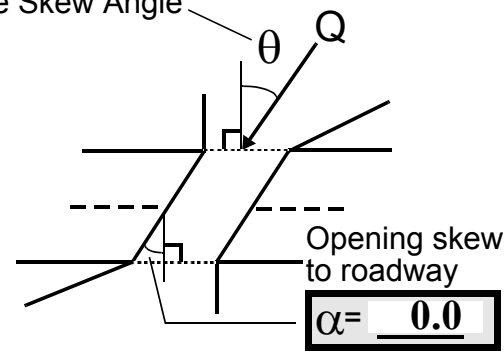

Range? 105 feet US

Channel impact zone 2:

Where? RB (LB, RB)

Severity 2

Range? 10 feet US

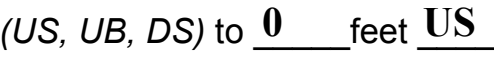

Exist? $\mathbf{Y}(Y$ or $N)$

Severity 2

Impact Severity: 0- none to very slight; 1- Slight; 2- Moderate; 3- Severe 
18. Bridge Type: $\underline{\mathbf{1 a} / \mathbf{1 b}}$

1a- Vertical abutments with wingwalls

1 b- Vertical abutments without wingwalls

2- Vertical abutments and wingwalls, sloping embankment Wingwalls perpendicular to abut. face

3- Spill through abutments

4- Sloping embankment, vertical wingwalls and abutments

Wingwall angle less than $90^{\circ}$.

19. Bridge Deck Comments (surface cover variations, measured bridge and span lengths, bridge type variations, approach overflow width, etc.)

\#7: The measured bridge width from rail to rail was 11.7 feet. The wooden deck excedes the boundaries of the rails.

\#18: The left abutment is type $1 \mathrm{~b}$. The right abutment is type $1 \mathrm{a}$.

\section{Upstream Channel Assessment}

\begin{tabular}{|c|c|c|c|c|c|c|c|c|c|c|}
\hline \multicolumn{5}{|c|}{ 21. Bank height (BF) 22. Bank angle (BF) } & \multicolumn{2}{|c|}{ 26. \% Veg. cover (BF) } & \multicolumn{2}{|c|}{ 27. Bank material (BF) } & \multicolumn{2}{|c|}{ 28. Bank erosion (BF } \\
\hline 20. SRD & LB & RB & LB & RB & LB & RB & LB & RB & LB & RB \\
\hline 31.5 & 6.0 & & & 4.5 & 3 & 1 & 432 & 234 & 2 & 1 \\
\hline 3. Ban & & & 24. & width & 15.0 & 25. $\mathrm{Tr}$ & eg dep & 2.5 & 9. Bed & 453 \\
\hline
\end{tabular}

30 .Bank protection type:

LB 2

RB 2

31. Bank protection condition: LB 2

RB 1

SRD - Section ref. dist. to US face \% Vegetation (Veg) cover: 1- 0 to 25\%; 2- 26 to 50\%; 3- 51 to $75 \%$; 4- 76 to $100 \%$

Bed and bank Material: 0- organics; 1- silt / clay, <1/16mm; 2- sand, 1/16 - 2mm; 3- gravel, 2 - 64mm;

4- cobble, 64 - 256mm; 5- boulder, > 256mm; 6- bedrock; 7-manmade

Bank Erosion: 0- not evident; 1- light fluvial; 2- moderate fluvial; 3- heavy fluvial / mass wasting

Bank protection types: 0- absent; 1- < 12 inches; 2- < 36 inches; 3- < 48 inches; 4- < 60 inches; 5- wall / artificial levee

Bank protection conditions: 1-good; 2- slumped; 3- eroded; 4- failed

32. Comments (bank material variation, minor inflows, protection extent, etc.):

\#30: Right bank protection is dumped stone. It is continuous protection extending from 35 feet upstream and along the upstream right wingwall, right abutment, downstream right wingwall and downstream right bank.

Left bank protection is dumped stone extending from 45 feet upstream to the upstream end of the left bank.

At 70 feet US there is a road which crosses through the stream channel, perpendicular to flow. 
33.Point/Side bar present? $\mathbf{Y}$

(Y or N. if $N$ type ctrl-n pb)34. Mid-bar distance: 65 US 35. Mid-bar width: 18 36. Point bar extent: $\underline{80}$ feet $\underline{\text { US }}$ (US, UB) to $\underline{\mathbf{2 5}}$ feet $\underline{\mathrm{US}}$ (US, UB, DS) positioned $\underline{\mathbf{4 0}} \%$ LB to $100 \%$ RB 37. Material: $4 \mathbf{5 3}$

38. Point or side bar comments (Circle Point or Side; Note additional bars, material variation, status, etc.):

The side bar begins where the road crosses the stream at 75 feet upstream. The material, on the left bank ramp where the road crosses the stream, consists of angular stone fill.

39. Is a cut-bank present? $\mathbf{Y}$ ( $Y$ or if $N$ type ctrl-n $c b)$ 40. Where? LB (LB or RB)

41. Mid-bank distance: 105 42. Cut bank extent: 145 feet $\underline{\text { US }}$ (US, UB) to $\underline{75}$ feet $\underline{\mathbf{U S}}$ (US, UB, DS)

43. Bank damage: 2 (1- eroded and/or creep; 2- slip failure; 3- block failure)

44. Cut bank comments (eg. additional cut banks, protection condition, etc.):

45. Is channel scour present? $\mathbf{Y}$ ( $Y$ or if $N$ type ctrl-n cs)

47. Scour dimensions: Length Width Depth : 46. Mid-scour distance: -

48. Scour comments (eg. additional scour areas, local scouring process, etc.):

Refer to downstream channel assessment for scour hole dimensions.

49. Are there major confluences? $\mathbf{N}$

51. Confluence 1: Distance Confluence 2: Distance 52. Enters on Enters on 54. Confluence comments (eg. confluence name):

NO MAJOR CONFLUENCES
50. How many? -

53. Type(1- perennial; 2- ephemeral)

Type (1-perennial; 2-ephemeral) (1-perennial, 2- ephemeral) ( $(L B$ or $R B)$ (LB or $R B)$ 
65. Debris and Ice Is there debris accumulation?

(Yor $N)$ 66. Where? $\underline{Y}$

(1- Upstream; 2- At bridge; 3- Both)

67. Debris Potential $\underline{3}$

( 1- Low; 2- Moderate; 3- High)

68. Capture Efficiency 2

(1-Low; 2- Moderate; 3- High)

69. Is there evidence of ice build-up? 2

Ice Blockage Potential $\underline{\mathbf{Y}}$

(1- Low; 2- Moderate; 3- High)

70. Debris and Ice Comments:

2

A decrease in the slope under the bridge, as well as the bridge location on the bend in the stream contribute to a moderate capture efficiency and ice blockage potential. Debris is presently caught in an I-beam at the upstream bridge face.

\begin{tabular}{|l|c|c|c|c|c|c|c|c|}
\hline Abutments & $\begin{array}{c}\text { 71. Attack } \\
\angle \text { (BF) }\end{array}$ & $\begin{array}{c}72 \text {. Slope } \angle \\
\text { (Qmax) }\end{array}$ & $\begin{array}{c}\text { 73. Toe } \\
\text { loc. (BF) }\end{array}$ & $\begin{array}{c}\text { 74. Scour } \\
\text { Condition }\end{array}$ & $\begin{array}{c}75 . \text { Scour } \\
\text { depth }\end{array}$ & $\begin{array}{c}\text { 76. Exposure } \\
\text { depth }\end{array}$ & 77. Material & 78. Length \\
\hline LABUT & & $\mathbf{0}$ & $\mathbf{9 0}$ & $\mathbf{2}$ & $\mathbf{2}$ & $\mathbf{0}$ & $\mathbf{3} \mathbf{f t}$ & $\mathbf{9 0 . 0}$ \\
\hline RABUT & $\mathbf{1}$ & $\mathbf{4 5}$ & $\mathbf{9 0}$ & & & $\mathbf{2}$ & $\mathbf{0}$ & $\mathbf{3 7 . 0}$ \\
\hline
\end{tabular}

Pushed: $L B$ or RB

Toe Location (Loc.): 0- even, 1- set back, 2- protrudes

Scour cond.: 0- not evident; 1- evident (comment); 2- footing exposed; 3-undermined footing; 4- piling exposed; 5- settled; 6- failed

Materials: 1- Concrete; 2- Stone masonry or drywall; 3- steel or metal; 4- wood

79. Abutment comments (eg. undermined penetration, unusual scour processes, debris, etc.):

0

0

1

The left abutment has a sand bar along the footing base described in the downstream channel assessment.

80. Wingwalls:

Exist? Material? Scour Scour Exposure 81. Condition? depth? depth?

USLWW:

37.0

USRWW: $\mathbf{N}$

DSLWW: -

DSRWW: 1

$$
1
$$

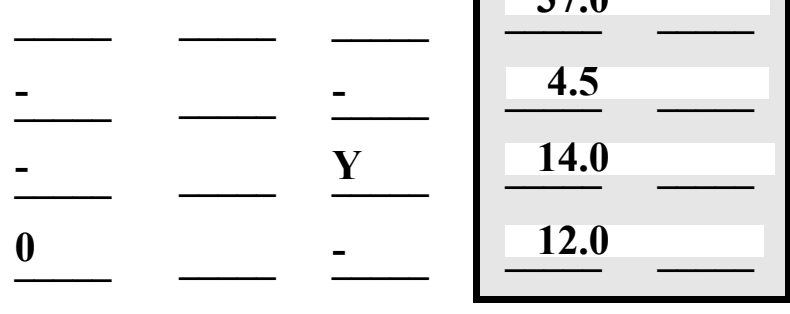

Wingwall materials: 1- Concrete; 2- Stone masonry or drywall; 3- steel or metal; 4- wood

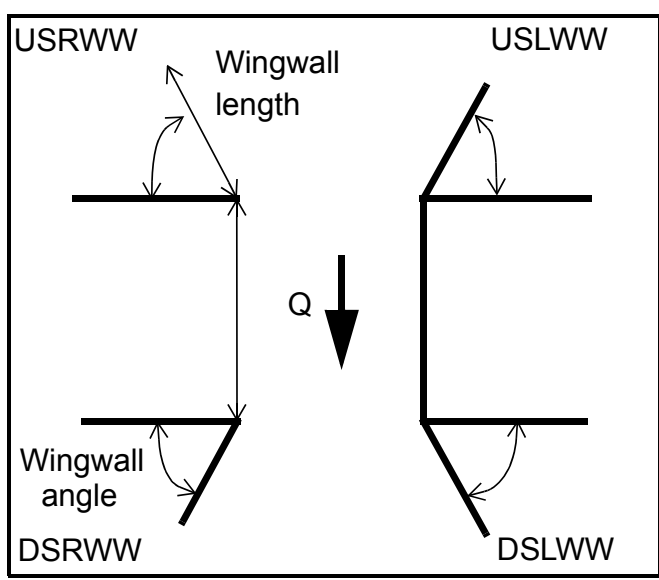

82. Bank / Bridge Protection:

\begin{tabular}{|l|l|l|l|l|l|l|l|l|}
\hline Location & USLWW & USRWW & LABUT & RABUT & LB & RB & DSLWW & DSRWW \\
\hline Type & - & - & Y & - & - & $\mathbf{1}$ & - & $\mathbf{1}$ \\
\hline Condition & $\mathbf{N}$ & - & $\mathbf{1}$ & - & - & $\mathbf{1}$ & - & $\mathbf{1}$ \\
\hline Extent & - & - & $\mathbf{0}$ & - & $\mathbf{2}$ & $\mathbf{0}$ & $\mathbf{2}$ & - \\
\hline
\end{tabular}

Bank / Bridge protection types: 0- absent; 1- < 12 inches; 2- < 36 inches; 3- < 48 inches; 4- < 60 inches; 
83. Wingwall and protection comments (eg. undermined penetration, unusual scour processes, etc.):

-
-
-
-
-
-
-
2
1
1

\section{Piers:}

84. Are there piers? Th (Y or if $N$ type ctrl-n pr)

\begin{tabular}{|l|l|l|l|l|l|l|l|}
\hline \multirow{2}{*}{$\begin{array}{l}85 . \\
\text { Pier no. }\end{array}$} & \multicolumn{3}{|c|}{ width (w) feet } & \multicolumn{3}{c|}{ elevation (e) feet } \\
\cline { 2 - 8 } & w1 & w2 & w3 & e@w1 & e@w2 & e@w3 \\
\hline Pier 1 & - & & & - & $\mathbf{5 5 . 0}$ & $\mathbf{1 5 . 0}$ \\
\hline Pier 2 & - & & & - & $\mathbf{6 0 . 0}$ & $\mathbf{1 3 . 5}$ \\
\hline Pier 3 & - & - & - & - & - & - \\
\hline Pier 4 & - & - & - & - & - & - \\
\hline
\end{tabular}

\begin{tabular}{|l|l|l|l|l|}
\hline Level 1 Pier Descr. & \multicolumn{1}{|c|}{1} & \multicolumn{1}{|c|}{2} & \multicolumn{1}{|c|}{3} & \multicolumn{1}{|c|}{4} \\
\hline 86. Location (BF) & ebank/ & e is & ends & Stacke \\
\hline 87. Type & brid & dum & (roa & d \\
\hline 88. Material & ge & ped & d & stone \\
\hline 89. Shape & pro- & stone & emb & exist \\
\hline 90. Inclined? & tec- & at & ank- & s at \\
\hline 91. Attack $\angle$ (BF) & tion & the & ment & the \\
\hline 92. Pushed & is & upst & s) of & dow \\
\hline 93. Length (feet) & - & - & - & - \\
\hline 94. \# of piles & dum & ream & the & nstre \\
\hline 95. Cross-members & ped & and & left & am \\
\hline 96. Scour Condition & stone & dow & abut & end \\
\hline 97. Scour depth & - & nstre & ment & of \\
\hline 98. Exposure depth & Ther & am & . & the \\
\hline
\end{tabular}

LFP, LTB, LB, MCL, MCM, MCR, RB, RTB, RFP

1- Solid pier, 2-column, 3- bent

1-Wood; 2- concrete; 3- metal; 4- stone

1- Round; 2- Square; 3- Pointed

Y-yes; $N$ - no

$L B$ or $R B$

0- none; 1- laterals; 2- diagonals; 3- both

0- not evident; 1- evident (comment);

2- footing exposed; 3- piling exposed;

4- undermined footing; 5- settled; 6- failed 
99. Pier comments (eg. undermined penetration, protection and protection extent, unusual scour processes, etc.):

\section{left abutment.}

100.

\section{E. Downstream Channel Assessment}

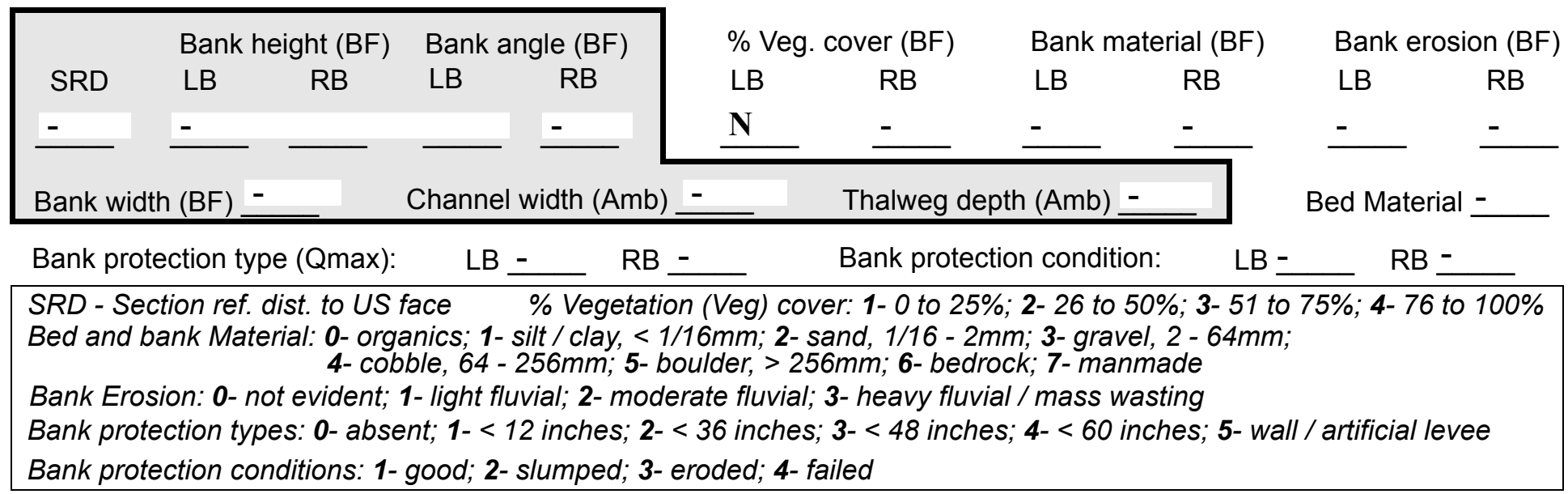

Comments (eg. bank material variation, minor inflows, protection extent, etc.):$$
-
$$$$
-
$$

$-$

$-$

$-$

$-$

$-$

$-$

$-$

$-$

$-$

$-$

$-$

$-$

$-$

\section{Is a drop structure present? __ ( $Y$ or $N$, if $N$ type ctrl-n $d s) \quad$ 102. Distance: ___ feet}

103. Drop: __ feet 104. Structure material: __ (1- steel sheet pile; 2- wood pile; 3- concrete; 4- other)

105. Drop structure comments (eg. downstream scour depth):

$-$

$-$

$-$

-

$-$

$-$ 
106. Point/Side bar present? (Y or $N$. if $N$ type ctrl-n pb)Mid-bar distance:

Mid-bar width: -

Point bar extent: feet -

(US, UB, DS) to feet (US, UB, DS) positioned $\%$ LB to $\% \mathrm{RB}$ Material:

Point or side bar comments (Circle Point or Side; note additional bars, material variation, status, etc.):

Is a cut-bank present? - (Y or if $N$ type ctrl-n cb) Where? NO (LB or RB) Mid-bank distance: PIE Cut bank extent: RS feet__ (US, UB, DS) to feet (US, UB, DS)

Bank damage: (1- eroded and/or creep; 2- slip failure; 3- block failure)

Cut bank comments (eg. additional cut banks, protection condition, etc.):

Is channel scour present? Scour dimensions: Length 2 Width 23 ( $Y$ or if $N$ type ctrl-n cs) Depth: 432 Mid-scour distance: $\mathbf{3}$ Scour comments (eg. additional scour areas, local scouring process, etc.): 345

2

2

2

Are there major confluences? 1 ( $Y$ or if $N$ type ctrl-n $m c)$ Confluence 1: Distance right Enters on ban ( $L B$ or RB) Enters on tec- ( $L B$ or $R B)$

Positioned 1 $\%$ LB to 1 $\%$ RB
How many? The

Type $\underline{\mathbf{k}}$ (1- perennial; 2- ephemeral) Type tion (1- perennial; 2- ephemeral)

Confluence comments (eg. confluence name):

extends from 35 feet upstream to 27 feet downstream. From 27 feet downstream to 68 feet downstream on the right bank, the protection type is also type 2 . However, there is more vegetation between the slumping placed

\section{F. Geomorphic Channel Assessment}

107. Stage of reach evolution pro

1- Constructed

2- Stable

3- Aggraded

4- Degraded

5- Laterally unstable

6- Vertically and laterally unstable 
108. Evolution comments (Channel evolution not considering bridge effects; See HEC-20, Figure 1 for geomorphic descriptors):

tection. A bedrock outcrop exists on the right bank from 68 feet downstream and beyond.

The left bank dumped stone protection ends at 17 feet downstream, and is slumped into channel. 


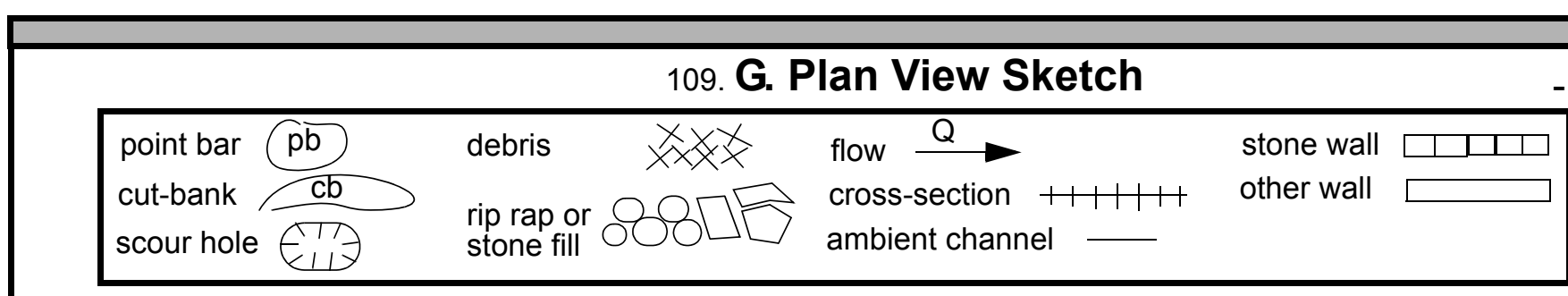


APPENDIX F:

SCOUR COMPUTATIONS 


\begin{tabular}{|c|c|c|c|}
\hline $\begin{array}{ll}\text { Structure Number: WOLCTH00130023 } \\
\text { Road Number: }\end{array}$ & & $\begin{array}{l}\text { Town : } \\
\text { County: }\end{array}$ & $\begin{array}{l}\text { WOLCOTT } \\
\text { LAMOILLE }\end{array}$ \\
\hline Stream: WILD BRANCH LAMOILLE RIVER & & & \\
\hline Initials ECW & Checked: & $\mathrm{EB}$ & $5 / 27 / 97$ \\
\hline Lysis of contrac & Ar & ear $\mathrm{w}$ & \\
\hline $\begin{array}{l}\text { Critical Velocity of Bed Material } \\
\text { Vc }=11.21 * 1^{\wedge} 0.1667 * \mathrm{D} 50^{\wedge} 0.33 \text { with Ss }\end{array}$ & $\begin{array}{l}\text { converted } \\
=2.65\end{array}$ & to Engl & sh units) \\
\hline (Richardson and others, 1995, p. 28 & , eq. 16) & & \\
\hline oproach section & & & \\
\hline Characteristic & $100 \mathrm{yr}$ & $500 \mathrm{yr}$ & other $\mathrm{Q}$ \\
\hline Total discharge, cfs & 4930 & 7180 & 3350 \\
\hline Main Channel Area, ft2 & 562 & 664 & 371 \\
\hline Left overbank area, ft2 & 187 & 340 & 17 \\
\hline Right overbank area, ft2 & 213 & 341 & 64 \\
\hline Top width main channel, ft & 53 & 53 & 53 \\
\hline Top width L overbank, ft & 71 & 88 & 18 \\
\hline Top width $\mathrm{R}$ overbank, ft & 57 & 71 & 35 \\
\hline D50 of channel, ft & 0.28 & 0.28 & 0.28 \\
\hline D50 left overbank, ft & -- & -- & -- \\
\hline D50 right overbank, ft & -- & -- & -- \\
\hline y1, average depth, MC, ft & 10.6 & 12.5 & 7.0 \\
\hline Y1, average depth, LOB, ft & 2.6 & 3.9 & 0.9 \\
\hline Y1, average depth, ROB, ft & 3.7 & 4.8 & 1.8 \\
\hline Total conveyance, approach & 93923 & 140289 & 38756 \\
\hline Conveyance, main channel & 70370 & 92908 & 35280 \\
\hline Conveyance, LOB & 6602 & 15510 & 320 \\
\hline Conveyance, ROB & 16951 & 31871 & 3156 \\
\hline Percent discrepancy, conveyance & 0.0000 & 0.0000 & 0.0000 \\
\hline Qm, discharge, $\mathrm{MC}$, cfs & 3693.7 & 4755.0 & 3049.5 \\
\hline Q1, discharge, LOB, Cfs & 346.5 & 793.8 & 27.7 \\
\hline Qr, discharge, ROB, cfs & 889.8 & 1631.2 & 272.8 \\
\hline $\mathrm{Vm}$, mean velocity $\mathrm{MC}$, ft/s & 6.6 & 7.2 & 8.2 \\
\hline Vl, mean velocity, LOB, ft/s & 1.9 & 2.3 & 1.6 \\
\hline Vr, mean velocity, ROB, ft/s & 4.2 & 4.8 & 4.3 \\
\hline Vc-m, crit. velocity, MC, ft/s & 10.9 & 11.2 & 10.1 \\
\hline Vc-l, crit. velocity, LOB, ft/s & ERR & ERR & ERR \\
\hline Vc-r, crit. velocity, ROB, ft/s & ERR & ERR & ERR \\
\hline Results & & & \\
\hline Live-bed(1) or Clear-Water(0) Contr & action $\mathrm{ScC}$ & our? & \\
\hline Main Channel & 0 & 0 & 0 \\
\hline Left Overbank & $\mathrm{N} / \mathrm{A}$ & $\mathrm{N} / \mathrm{A}$ & $\mathrm{N} / \mathrm{A}$ \\
\hline Right Overbank & $\mathrm{N} / \mathrm{A}$ & $\mathrm{N} / \mathrm{A}$ & $\mathrm{N} / \mathrm{A}$ \\
\hline
\end{tabular}


Clear Water Contraction Scour in MAIN CHANNEL

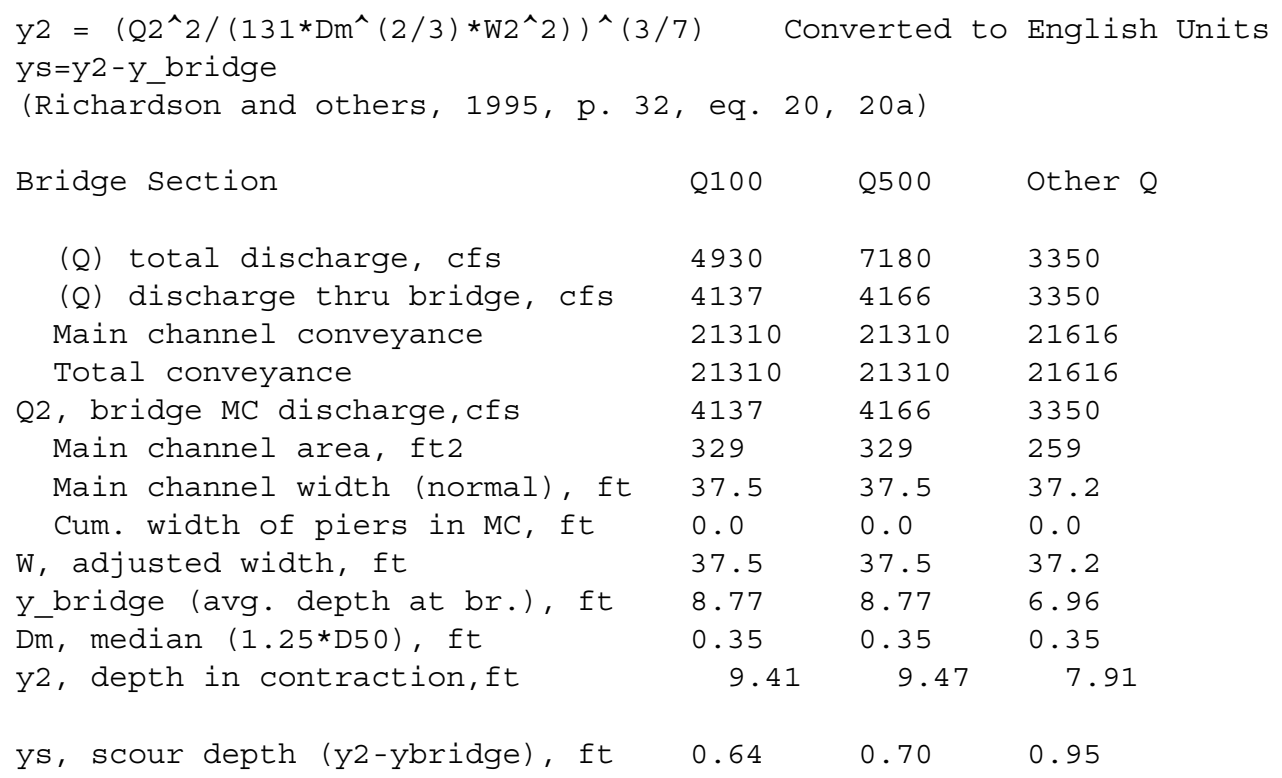




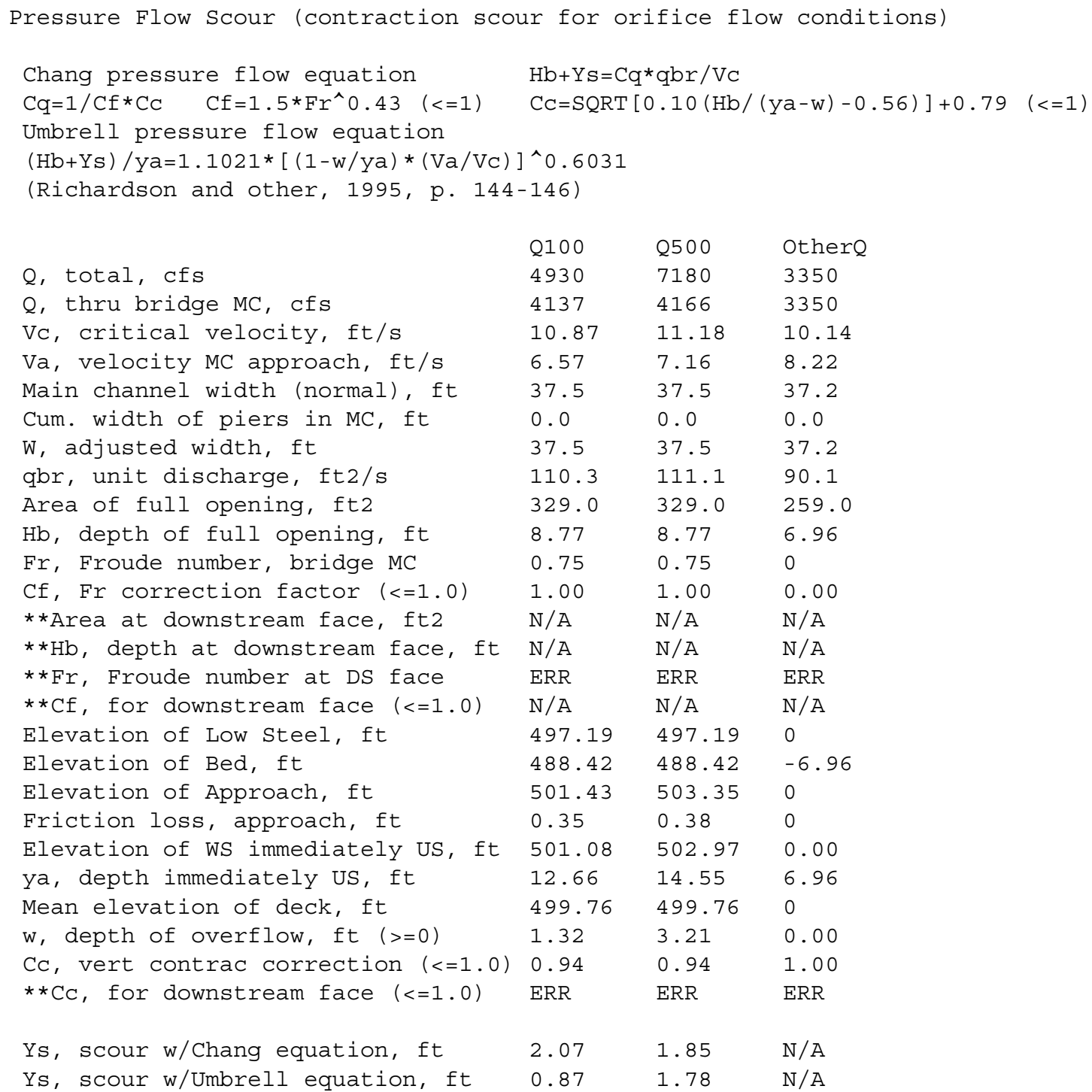




\begin{tabular}{|c|c|c|c|}
\hline \multicolumn{4}{|c|}{$\begin{array}{l}\mathrm{DC}=\left[\left(1.94 * \mathrm{~V}^{\wedge} 2\right) /(5.75 * \log (12.27 * \mathrm{y} / \mathrm{D} 90))^{\wedge} 2\right] /[0.03 *(165-62.4)] \\
\text { Depth to Armoring }=3 *(1 / \mathrm{PC}-1) \\
\text { (Federal Highway Administration, 1993) }\end{array}$} \\
\hline Downstream bridge face property & $100-\mathrm{yr}$ & $500-y r$ & Other $Q$ \\
\hline Q, discharge thru bridge $\mathrm{MC}$, cfs & 4137 & 4166 & 3350 \\
\hline Main channel area (DS), ft2 & 329 & 329 & 259 \\
\hline Main channel width (normal), ft & 37.5 & 37.5 & 37.2 \\
\hline Cum. width of piers, ft & 0.0 & 0.0 & 0.0 \\
\hline Adj. main channel width, ft & 37.5 & 37.5 & 37.2 \\
\hline D90, ft & 0.6281 & 0.6281 & 0.6281 \\
\hline D95, ft & 0.7932 & 0.7932 & 0.7932 \\
\hline Dc, critical grain size, ft & 0.6040 & 0.6125 & 0.7006 \\
\hline PC, Decimal percent coarser than DC & 0.108 & 0.105 & 0.077 \\
\hline Deptl & 14.97 & 15.66 & 25.19 \\
\hline
\end{tabular}

Abutment scour

Froehlich's Abutment Scour

$\mathrm{Ys} / \mathrm{Y} 1=2.27 * \mathrm{~K} 1 * \mathrm{~K} 2 *\left(\mathrm{a}^{\prime} / \mathrm{Y} 1\right)^{\wedge} 0.43 * \mathrm{Fr} 1^{\wedge} 0.61+1$

(Richardson and others, 1995, p. 48, eq. 28)

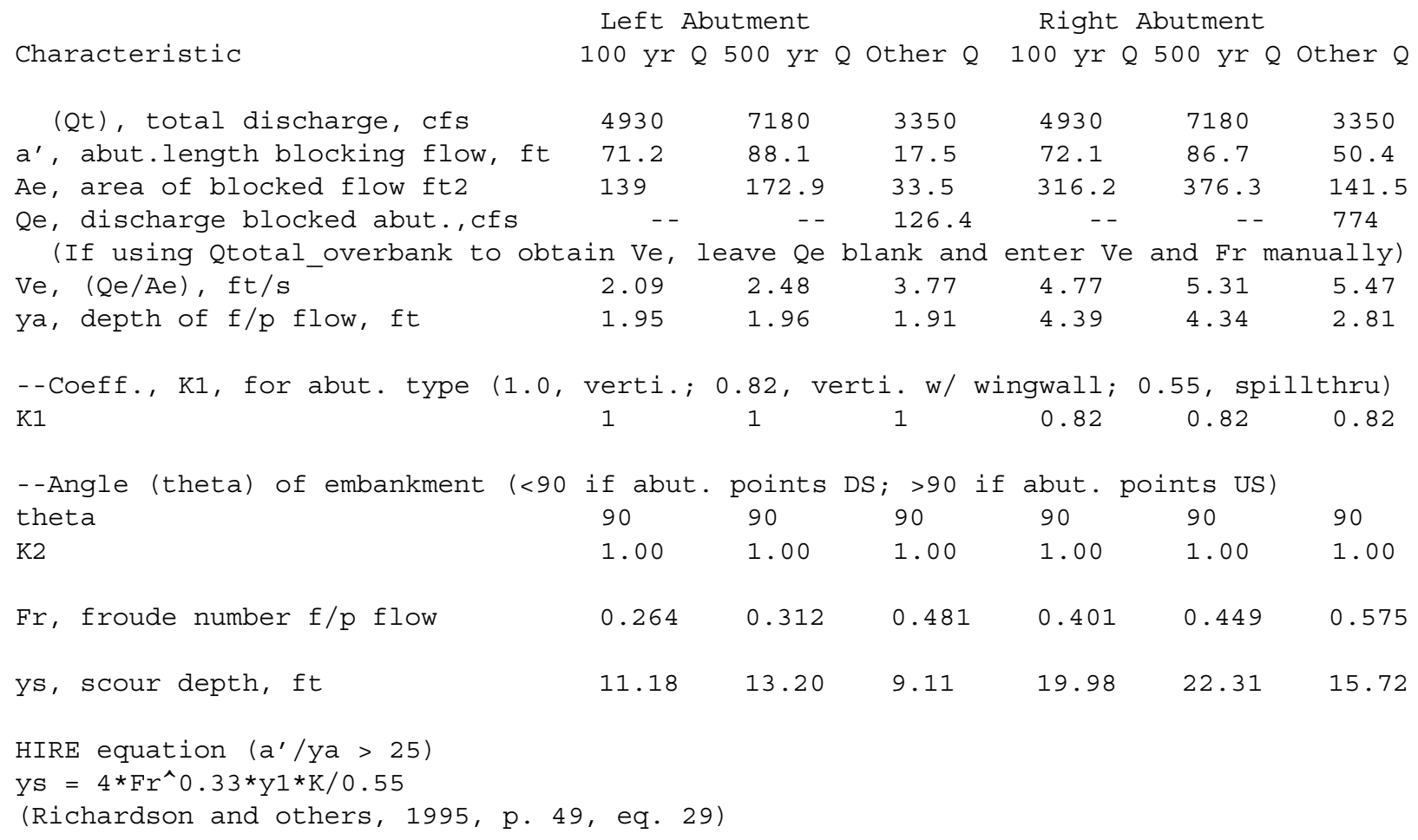




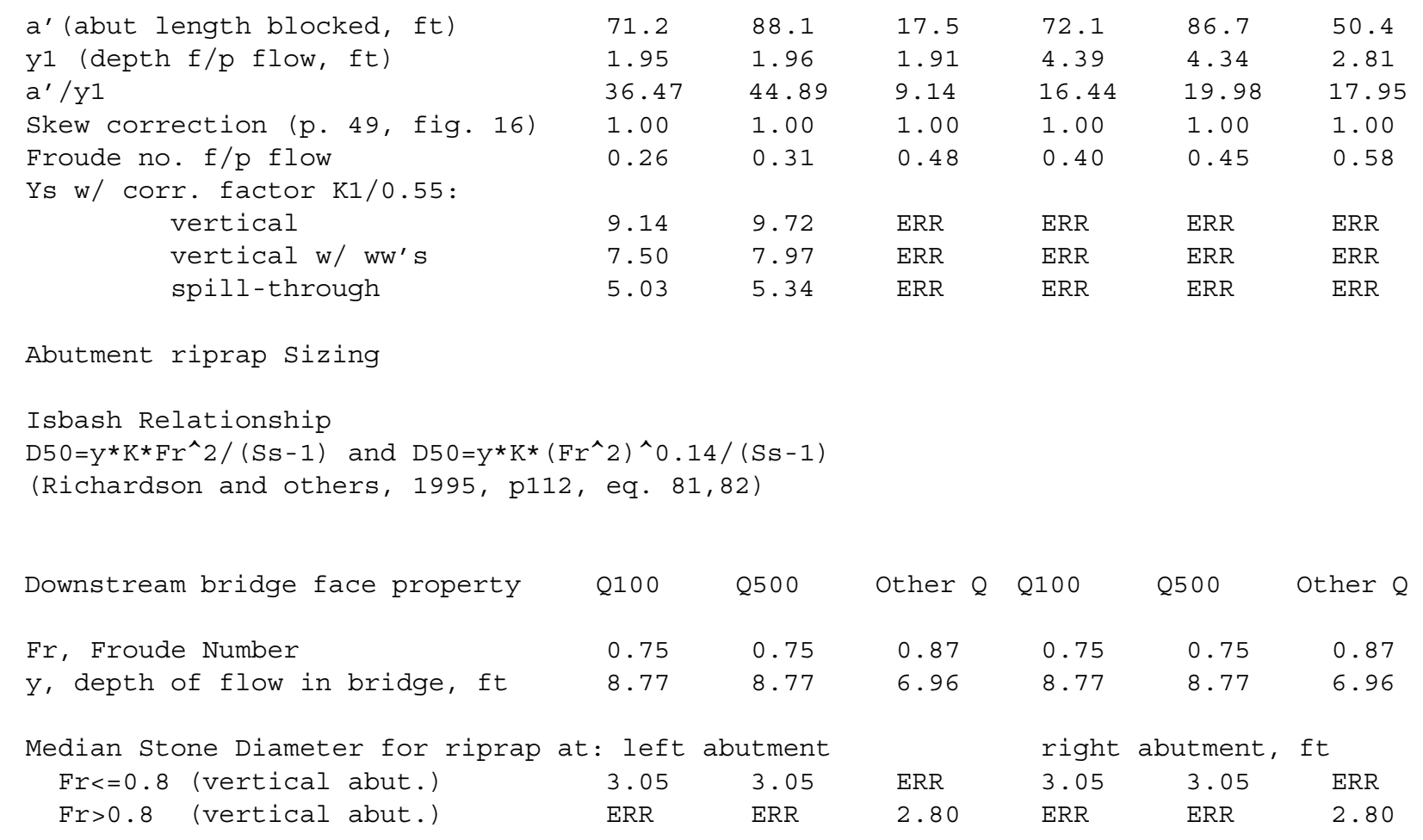

